\title{
Research Paper An Investigation of Psychometric Properties of Wisdom Assessment Scale for Students
}

\author{
Mohammadali Salmaniardani ${ }^{1}$, Mansureh Shahriariahmadi ${ }^{* 2}$, Mahdi Davaee ${ }^{3}$ \\ 1. Ph.D. Student of Psychology and Exceptional Children Education, Central Tehran Branch, Islamic Azad University, Tehran, Iran \\ 2. Assistant Professor, Department of Psychology of Exceptional Children, Central Tehran Branch, Islamic Azad University, Tehran, \\ Iran \\ 3. Assistant Professor, Department of Educational Sciences, Central Tehran Branch, Islamic Azad University, Tehran, Iran
}

Citation: Salmaniardani M, Shahriariahmadi M, Davaee M. An investigation of psychometric properties of wisdom assessment scale for students. J Child Ment Health. 2021; 7(4): 129-147.

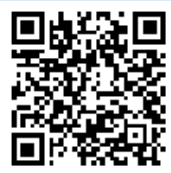

URL: http://childmentalhealth.ir/article-1-1042-en.html

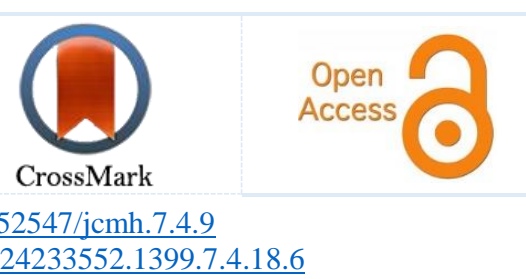

A R T I C L E I N F O

\section{Keywords:}

Wisdom assessment

scale,

psychometric properties, students

Received: 2 Aug 2020

Accepted: 6 Nov 2020

Available: 9 May 2021

\section{A B S T R A C T}

Background and Purpose: Strengthening the wisdom alongside the intelligence is essential for students' spiritual and scientific progress. Accordingly, the behavioral indicators and the level of wisdom of students should be measured with a valid and reliable tool in accordance with the Islamic culture. This study aims to investigate the psychometric properties of the wisdom assessment scale for adolescent students, constructed by Salmaniardani, Shahriariahmadi, and Davaee.

Method: This research was an applied-developmental and a descriptive-survey study in the method of gathering the data. The study population included all the high-IQ students and average-IQ students of the first cycle of the secondary school in Isfahan in the academic year 2018-2019. Cluster random sampling was used and 400 students were individually tested by the questionnaire for measuring the wisdom. Data were analyzed by SPSS and AMOS software using correlation coefficient and exploratory and confirmatory factor analysis.

Results: The results of factor analysis showed that the eight factors of general wisdom, religious wisdom, emotional wisdom, human wisdom, spiritual wisdom, moral wisdom, social wisdom, and scientific wisdom with eigenvalues higher than one explained $71.49 \%$ of the variance of items. The results of the first-order confirmatory factor analysis showed that the model fit index was optimal. The reliability of the questionnaire calculated by Cronbach's alpha was 0.895 .

Conclusion: The coordination between the factors and the total score is acceptable and the model fit index is optimal, indicating the adequacy of the questionnaire.

* Corresponding author: Mansureh Shahriariahmadi, Assistant Professor, Department of Psychology of Exceptional Children, Central Tehran Branch, Islamic Azad University, Tehran, Iran.

E-mail: Mansure_shahriari@yahoo.com

Tel: (+98) 2122481750

2476-5740/ () 2021 The Authors. This is an open access article under the CC BY-NC-ND license

(https://creativecommons.org/licenses/by-nc-nd/4.0/). 


\section{Extended Abstract}

\section{Introduction}

Wisdom is among the significant cognitive constructs. Sternberg, among others, suggests that intelligence is not sufficient to address the complex real-world problems (1). Wisdom is the advanced form of intelligence and other thinking skills (6) that goes beyond intelligence and knowledge and includes dimensions like self-thinking, openness, compassion and ethics. Levenson, Jennings, Aldwin, \& Shiraishi define wisdom in terms of selftranscendence which involves independence and overcoming the boundaries of individual self (9). While some definitions consider wisdom as a competency, others measure it as an attitude or trait, i.e. a method of experiencing and thinking in life which includes the tendency to find meaning, to develop, to reach satisfaction, to have open and compassionate attitude towards others, and to think deeply and critically (12).

Concerning the dimensions of wisdom, Staudinger $\&$ Gluck argue that the psychological definitions of wisdom can be divided into general wisdom; i.e. the wisdom related to the questions of human life and the world in general, and personal wisdom, which is associated with self-experiences in life (14). In this regard, results of Kord Noghabi, Delfan Biranvand, \& Arablo showed that the characteristics of being wise include religiosity and ethics, thinking/awareness, perception of facts, lack of subjectivity, empathy/emotion, support/serving, relationship, gain experience, and cultural values (16).

The important mission of each educational system is to develop thinking and to improve the higher functions like wisdom and rationality (23) in addition to the intelligence. This depends on applying a valid and reliable scale in consistency with the Islamic culture to measure wisdom; in such a way that the strengths and weaknesses of the students are specified and then the appropriate training is provided to reinforce the behavioral factors of wisdom in them. It is worth mentioning that foreign scales have been used to assess wisdom of students, but their contents were not completely adjusted to the existing culture. Some non-Persian and non-native tools include wisdom scales of Schmit, Muldoon, \& Pounders (18),
Webster (19), and Dean Webster (20). In Iran, the only scale to measure wisdom is a questionnaire primitively compiled by Salmani, Shahriari, \& Davaee (29). Therefore, this study aimed to investigate the psychometric properties of this questionnaire on a group of adolescent students.

\section{Method}

This study was an applied- developmental study in its objective and a descriptive-survey study in gathering the data. To investigate the psychometric properties of the wisdom assessment scale for adolescent students constructed by Salmani, Shahriari, \& Davaee (29), the exploratory and confirmatory method was used with psychometric techniques. The study population $(\mathrm{N}=52813)$ included all the male and female adolescent students of the first cycle of the secondary school in Isfahan in the academic year 2018-2019 (1711 high-IQ students and 51102 average-IQ students). Through using Krejcie \& Morgan table, 400 male and female students with high and average IQ were selected by cluster sampling, based on the inclusion and exclusion criteria (200 per group). The inclusion criteria were studying at the first cycle of the secondary school and being of the same age, same educational level, same culture, and same domicile place. The exclusion criterion included not being motivated to complete the questionnaire. It is worth mentioning that the measure to determine high IQ in this study was assessment made by National Organization for Development of Exceptional Talents and studying at the centers for exceptional talents. Data were collected by Wisdom Assessment Scale for Adolescent Students (29). This scale measures the construct of wisdom as a total score and at eight sub-scales, including general wisdom, religious wisdom, emotional wisdom, human wisdom, spiritual wisdom, moral wisdom, social wisdom, and scientific wisdom. Upon implementation of the questionnaire on the sample, data were analyzed by exploratory and confirmatory factor analysis by SPSS and Amos.

\section{Results}

a) Validity: validity of the questionnaire was determined by factor analysis. By conducting factor analysis on the items, taking into account the high 
value of correlation between the items, and assuring that the items have the required adequacy, the final data analysis was conducted by principal components analysis with varimax rotation. Therefore, to determine the factors of the questionnaire, three major indicators of eigenvalue, relation of variance explained by each factor and scree plot were used. Results of exploratory factor analysis showed that eight factors had eigenvalues higher than 1 . The variance explained by each of the factors was as follows: 15.596 by the first factor (general wisdom), 13.529 by the second factor (religious wisdom), 13.180 by the third factor (emotional wisdom), 13.019 by the forth factor (human wisdom), 10.665 by the fifth factor (spiritual wisdom), 5.343 by the sixth factor (moral wisdom), 3.140 by the seventh factor (social wisdom), and 2.366 by the eighth factor (scientific wisdom). In general, these eight factors explained $71.494 \%$ of the total variation. Also, the first-order confirmatory factor analysis was done based on maximum likelihood estimation and indicators of goodness of fit of structural equation models including Chi-square/degree of freedom ratio, parsimonious normed fit index, comparative fit index, parsimonious comparative fit index, incremental fit index, goodness of fit index, and root mean square error of approximation. Results of first-order confirmatory factor analysis by Amos software showed that the eight-factor structure of the questionnaire is fitted to the data.

Results of this study also indicated that the acceptable correlation between the factors and the total score (0.482 and 0.811$)$ and weak correlation between the eight factors $(0.288$ and 0.573$)$ implied the convergent and divergent validity of the scale.

b) Reliability: To assess the reliability, Cronbach's alpha and split-half method were used. Cronbach's alpha showed the reliability of 0.895 for the total score, 0.756 for the first factor (general wisdom), 0.727 for the second factor (religious wisdom), 0.715 for the third factor (emotional wisdom), 0.712 for the fourth factor (human wisdom), 0.700 for the fifth factor (spiritual wisdom), 0.702 for the sixth factor (moral wisdom), 0.680 for the seventh factor (social wisdom) and 0.672 for the eighth factor (scientific wisdom). Also, the Cronbach's alpha was 0.818 for the first half and 0.824 for the second half. The split half correlation coefficient was 0.84 .

\section{Conclusion}

Present study was conducted to investigate the psychometric properties of the questionnaire constructed by Salmani, Shahriari, \& Davaee (29). Results of exploratory factor analysis to assess validity of the questionnaire showed that this questionnaire has 8 factors and results of confirmatory factor analysis confirmed it. Also, low correlation between the eight factors and relatively high value of correlation coefficient between these factors and the total score indicated convergent and divergent validity. Reliability of the questionnaire was confirmed by Cronbach's alpha of 0.895 .

Accordingly, it can be concluded that the scale constructed by Salmani, Shahriari, \& Davaee has the optimal psychometric properties. It is worth mentioning that the factors confirmed are consistent with some dimensions of wisdom scales of Schmit, Muldoon, Pounders (18), Webster (19), and Dean Webster (20). In general, based on the results of this study it can be concluded that the wisdom assessment scale made by Salmani, Shahriari, \& Davaee (29) is an appropriate tool for measuring wisdom in adolescent students and it can be used by the researchers. 


\section{Quarterly Journal of Child Mental Health}

Vol. 7, No. 4, Winter 2021

\section{Ethical Considerations}

Compliance with ethical guidelines: The permission for carrying out this study on the sample participants was issued by Isfahan Education Administration, bearing Letter No. 1700/424326/650 dated 11 Mar. 2019. Also, other ethical considerations like gaining the informed consent of the participants and the confidentiality were observed in this research.

Funding: This study was conducted as a Ph.D. thesis with no financial support.

Authors' contribution: This study was extracted from the $\mathrm{Ph}$.D. dissertation of Mr. Mohammadali Salmaniaradani, in the field of Psychology and Education of Exceptional Children at
Central Tehran Branch of Islamic Azad University, with the thesis code of 10120707972021 and thesis defense session dated 26.10.2020. The second author was the supervisor and the third author was the advisor.

Conflict of interest: There is no conflict of interest in this study and the results have been reported clearly with no bias.

Acknowledgments: We would like to appreciate the authorities of Isfahan Education Administration, especially the expert of research who made the required collaborations for conducting the questionnaire on the sample students. Also, we sincerely thank the administrative staff, the teachers and the sample individuals for their kind cooperation. 


\title{
تعيين ويزگى هاى روانسنجى ثرسشنامه سنجش خردمندى دانش آموزان
}

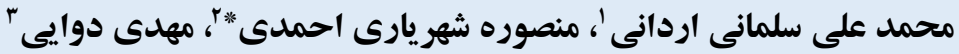

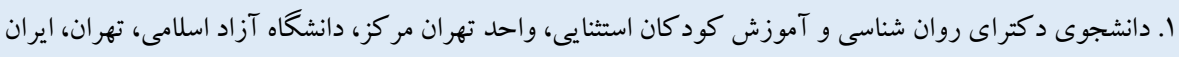

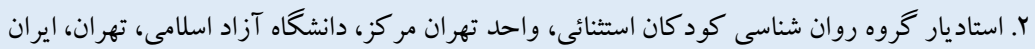

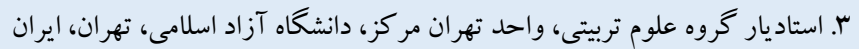

زمينه و هدف: تقويت خردمندى در كنار هوشمندى براى ييشرفت معنوى و علمى دانش آموزان موضوعى ضرورى است. بدين ترتيب بايد

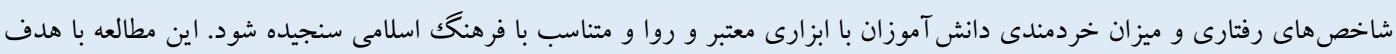

بررسى ويز گیىهاى روانسنجى برسشنامه سنجش خردمندى دانش آموزان سلمانى، شهريارى و دوايى، انجام شده است. روش: مطالعه حاضر به لحاظ هدف جزء ئزوهشهاى توسعهاى - كاربردى و به لحاظ شيوه گرد دآورى دادهها از نوع توصيفى- بيمايشى

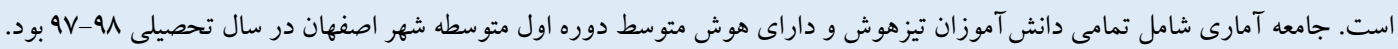

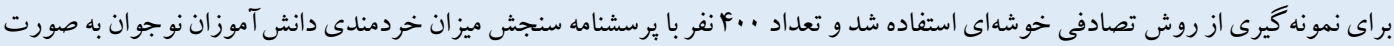

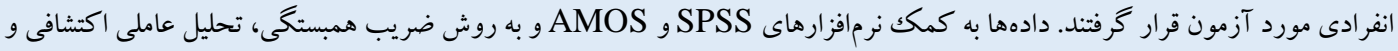
تأييدى تحليل شدند.

يافته ها: نتايج تحليل عاملى نشان داد كه هشت عامل خردمندى عمومى، خردمندى دينى، خرمندى عاطفى - هيجانى، خردمندى انسانى،

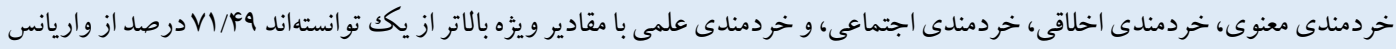

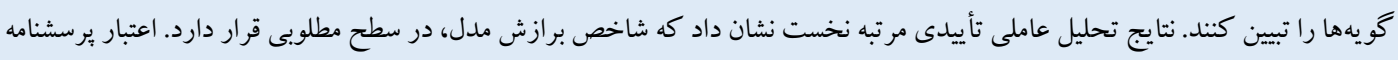

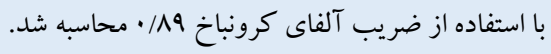

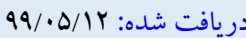
نتيجه كيرى: هماهنكى بين عوامل با نمره كل قابل قبول است و شاخص برازش مدل، در سطح مطلوبى قرار دارد كه نشان مىدهد ير سشنامه 
بايانى ايده آل تحول انسـانى، انخيزهُ اصـلى مطالعه در زمينه روانشـناسى

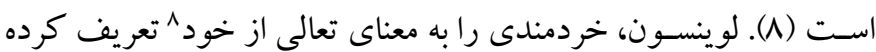

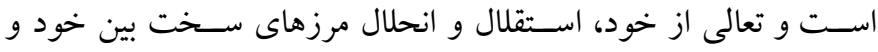

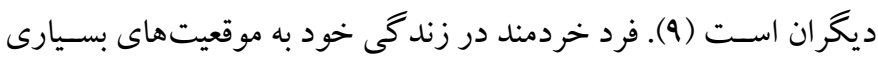

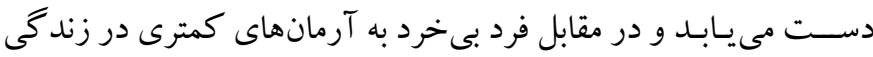

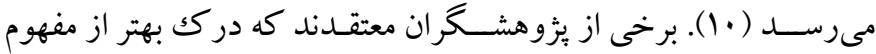

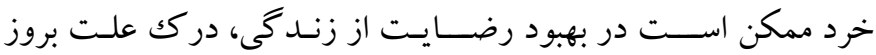

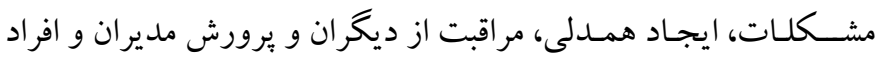
دار قاى قدرت رهبرى و توسعه قدرت در مواجهه با كشاكش ها مؤثر باشد (11). به طور خلاصسه، در حالى كه برخى تعاريف، خرد را به عنوان يكك

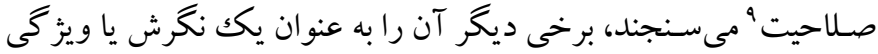

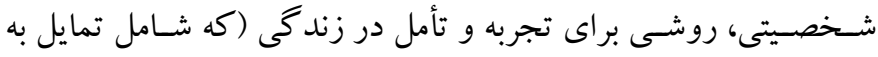

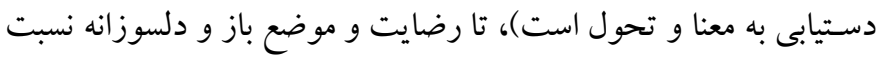

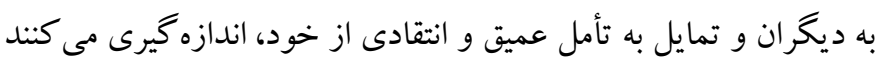

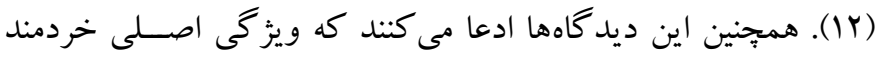
بودن، ايجاد سـاختار شخصيتى است كه افر اد را به سمت بينش ' مبتى بر تجربه سـوق مىدهد و حاصـل اين تجربيات، تحول مناسـب فرد اسـت

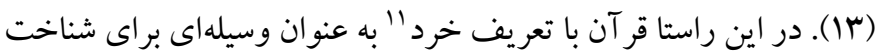

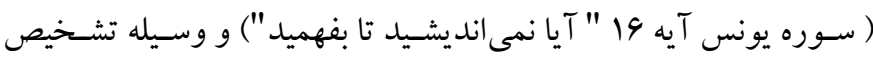

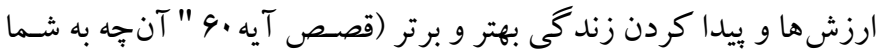
داده شده كالا و ابزار زندگى دنيا و زينت آن است، و آنجه نزد خداست

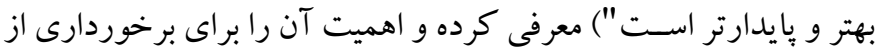

$$
\text { يك زندگى ايده آل بيان مى كند. }
$$

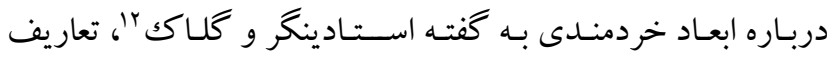
روانشـناختى از خردمندى را مىتوان به دو دســه تقسيم كرد: خرد

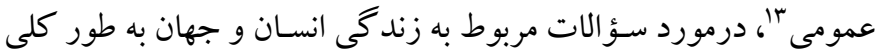

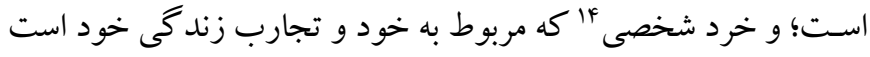

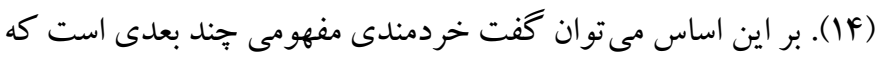

\section{Excellence of self}

9. Competence

10. Intuition

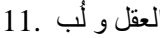

12. Staudinger \& Gluck

13. General wisdom

14. Personal wisdom

مقلدمه

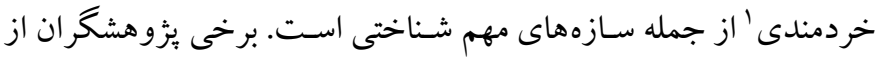

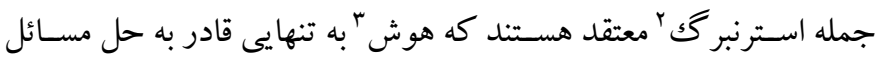
ييجيده امروزى نيست (1). در حال حاضر تحول مهارتهاى شناختى در دانش آموزان به حداقل رســيده اســت و حتى در جوامع مذهبى، تحول

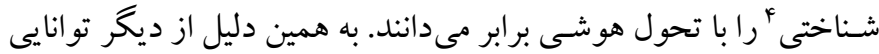

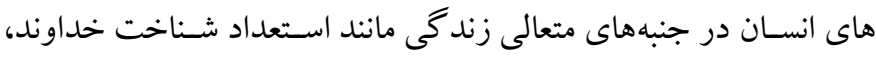

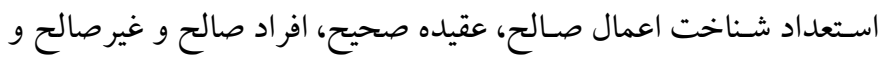
اخلاقيات، غفلت شـده اسـت (Y). مطالعات نشـان دادهاند كه در هر نسـل (هر ·r سـال)، ميزان بهره هوشى حدود 9 نمره افزايش داشـته است و هر

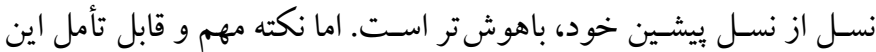
اسـت كه در برابر اين افزايش ضـريب هوشى، در دنيا جه تغييراتى انجام

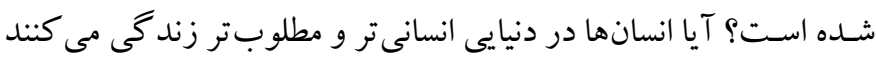

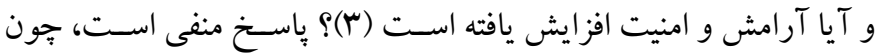

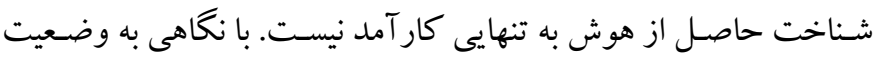

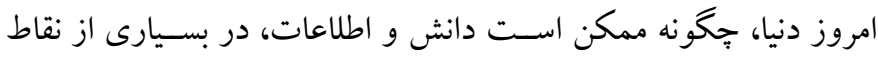

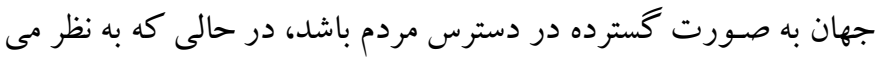

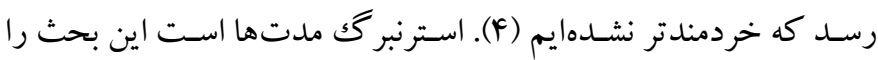
مطرح مى كند كه ما بايد بيش از اين كه هوش و دانش را به فرزندان خود آموزش دهيم بايد بفهميم كه جگگونه خرد را يرورش دهيم (ه).

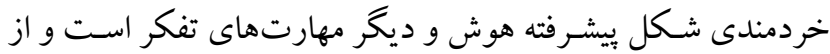

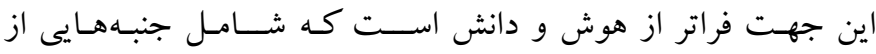

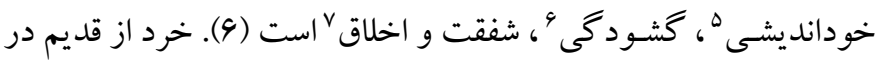

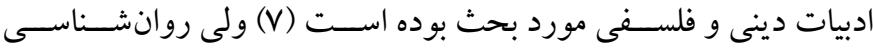

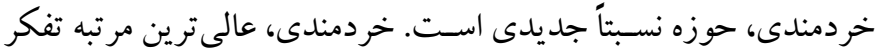

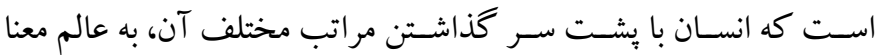

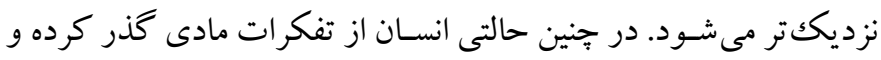

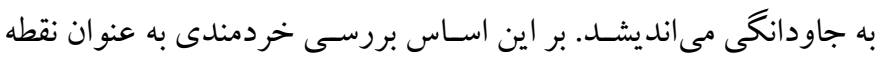

1. Wisdom

2. Sternberg

3. Intelligence

4. Cognitive evolution

5. Self-thinking

6. Openness

7. Compassion \& Ethics 
بخندم" (شوخ طبعى •r) (19 و ·r). آردلت، يرايدگن و نوتريرايدگن هم خردمندى را به عنوان تر كيبى از ويز گیى هاى شخصيتى با سه بعد گسترده

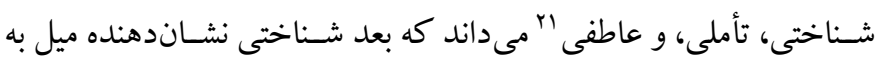

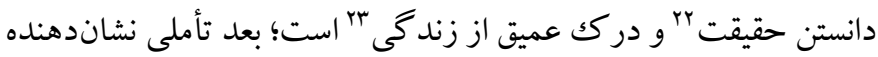

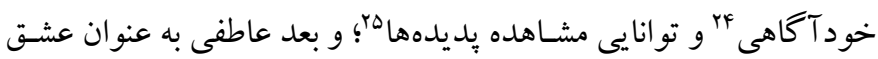
همدلانه و دلسوزانه نسبت به ديخر ان צ' تعريف شده است (YI). آردلت، يرايدگن و نوتريرايدگن دريافتند كه خرد به طور كلى يك منحنى U شـكل معكوس را نشـان مى دهد و آموزش بر شـكل منحنىها تأثير مى گذارد و اين موضـوع بدين معنا اسـت كه آموزش ممكن اسـت خرد را در ســالهـاى جوانى تقويت، و از حفظ آن در مراحل بعدى زنـــى حمـايست كنــ (YI). بنابراين امروزه به تأكيد بيشــرى بر ارتقا خردمندى از طريق سيستمهاى آموزشى ما از ابتدايى تا حرفهاى نياز است (V)؛ زيرا كه حل مسـائل بييجيده و شناخت حداكثرى و عمل به ارزش ها،

$$
\text { نتيجه آموزش و تقويت سازه خردمندى است. }
$$

ييـامبر اســلـام (ص) در اهميت خردمندى مىفرمايد: همه خوبىها با عقل شـناخته مىشوند و كسى كه صاحب خرد نيست، دين ندارد (به نقل از YY). بر اين اســاس مى توان كفت: رســالت مهم هر نظام آموزشـىى، يرورش تفكر و افزايش كـاركردهاى عالى از جمله خردمندى و عقلانيت در كنار هوشمندى اسـت (Yr). اين نكته به اين موضوع بستكى دارد كه يرسـشنامهاى معتبر و روا به عنوان ابزارى قابل اعتماد و متناسب با فرهنك اســلـامى، براى اندازه گيرى خردمندى مورد اســتفاده قرار گيرد تا نقاط ضف و قوت دانش آموزان در اين زمينه مشخص و از طريق آموزش هاى منـــــب، شــاخص هـاى رفتارى خردمندى در آنان تقويت شـــود. لرد كلوين 'VV معتقد است اكر بتوانيد آنجه را كه در بارهاش صحبت مى كنيد،

15. Self-Assessed Wisdom Scale (SAWS)

16. Vital life experience

17. Openness

18. Adjust emotions

19. Reflective

20. Humor

21. Cognitive, reflective \& emotional

22. The desire to know the truth

23. Deep understanding of life

24. Self-awareness

25. Ability to observe phenomena

26. Empathetic and compassionate love for others

27. Lord Kelvin
ابعـاد گونـاكون آن يكـديخر را تقويـت مى كنــد (با). جســت و لى'

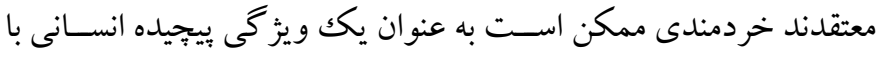
جندين مؤلفه خاص تعريف شــود كه بيامدهاى مهمى در سـطح فردى و

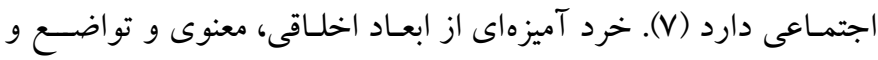

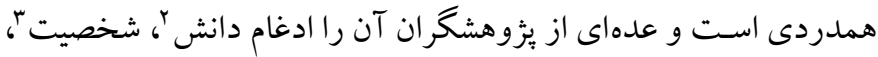

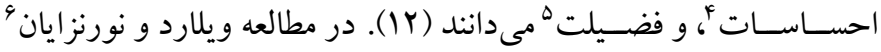
درباره عوامل مؤثر بر خردمندى، به يايبندى مذهبى اشاره شده است (ها (1)

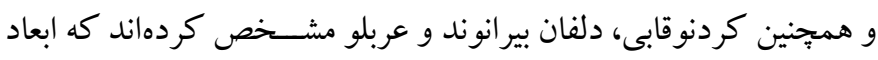

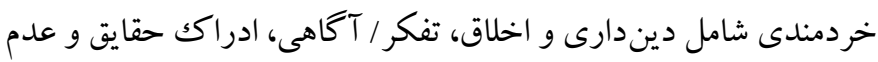

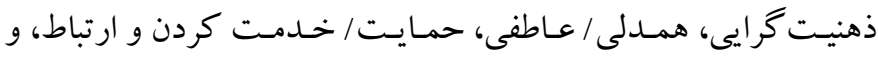

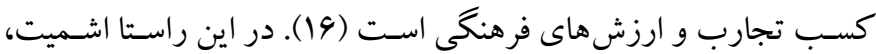

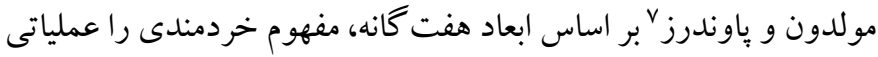

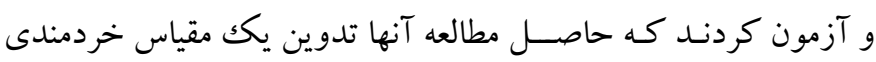

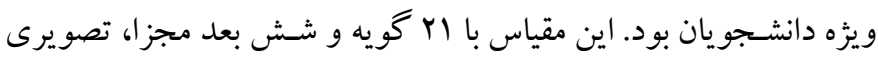
قابل قبول و روشن از بعديذيرى، روايى و يايايى خردمندى ار ائه مىدهد.

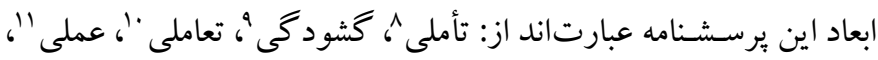

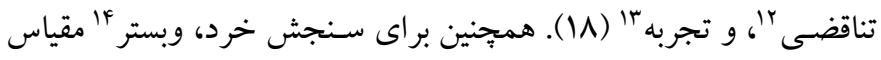

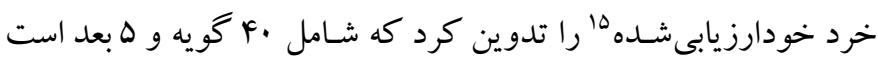
(هشت گويه در هر بعد) از جمله "من مجبور شدهام بسيارى از تصميمات

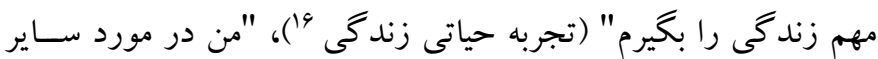

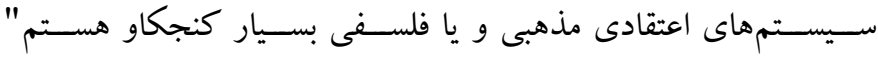

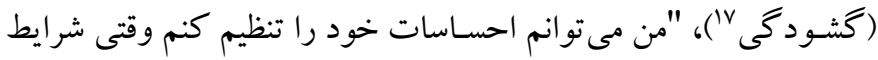

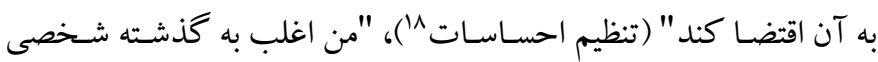

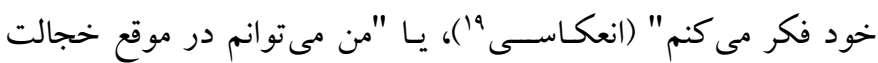

1. Jeste \& Lee

2. Knowledge

3. Character

4. Emotions

5. Virtue

6. Willard \& Norenzayan

7. Schmit, D.; Muldoon, J; Pounders,

8. Reflective

9. Openness

10. Interactive

11. Practical

12. Contradictory

13. Experiential

14. Webster 
باشــــ (YF). براين اســاس با اســتفاده از جدول نمونه گيرى كرجسـى مور كانّا، نمونه بزوهش بالاتر از ســطح مطلوب به تعداد . F. دانش آموز دختر و بِسـر تيز هوش و با هوش متوسـط (از هر خروه ... نفر) با روش نمونه گيرى تصـادفى خوشـهاى انتخاب شـدهاند. در ابن نوع نمونه گيرى

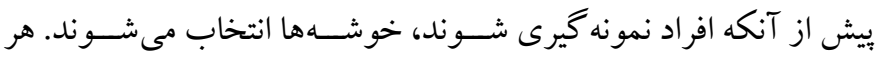
خوشـه شـامل بيش از يكك عنصـر اسـتغ ماند يكك مدرسـه يا يكك كلاس (Y9). در زمان انجام اين ثزؤهش، شـهر اصـفهان از شـش ناحيه آموزشى تشـكيل شـده بود و تنها در سـه ناحيه آن مدارس تيزهوش وجود داشت. بلدين ترتيب از جهار مدرسه تيزهوش دخترانه و يسر انه (دو مدرسه يسر انه و دو مدرســه دخترانه) به طور تصــادفى، شـش كلاس از بايههاى اول انتخـاب، و از بين دانش آموزان بـايسه اول، ا91 انفر در نمونه قرار گرفتند. براى بيشخيرى از ريزش احتمالى هادرصد به تعداد نمونه اضافه شد. لازم

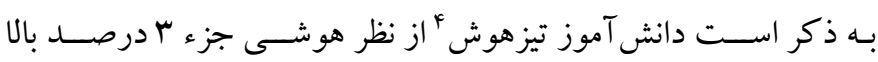
جمعيت اســت، بهره هوشـى بالاتر از ·ـا دارد، و اغلب از توانايىها يا اسـتعدادهاى ويزٔاى برخوردار اسـت (YV). ملاكك تيزهوش بودن در اين مطالعه، بر اسـاس سنجش انجام شده توسط سازمان استعدادهاى درخشان ايران و تحصــــل در مراكز تيزهوشــان بود. براى آن كـه دانش آموزان

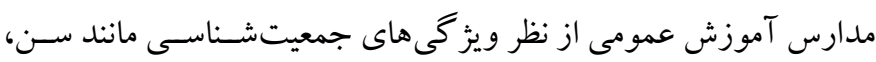
بايه تحصـيلى، فرهنگك، اقتصـاد و محل سـكونت، شــباهت بيشـترى با دانش آموزان تيز هوش داشـته باشـند، نمونه دانش آموزان با هوش متوسط هم بـهـ تعـداد |9| انفر و بـا در نظر كرفتن ريزش احتمـالى، از همين ســـه ناحيه انتخاب شـــ. لازم به ذكر اسـت كه در ايران دانش آموزان با هوش متوسـط به كسـانى كفته مى شـود كه داراى هوشـبهر هم تا • با هسـتند؛ يعنى از يكك انحراف يايين تر از ميانگين تادو انحراف بالاتر از ميانگين بر اسـاس مقياس هوشى و كسلر. بدين ترتيب طبق فهرست موجود در اداره آموزش و برورش متوسـطه نواحى شـهر اصـفهان، از بين تمامى مدارس متوسـطه دختر انه و يسـر انه آموزش عمومى، ابتدا شـش مدرسـه، و از بين يـايسهـهـاى اول اين مـدارس، شــش كلـاس بـه طور تصــادفى انتخاب و دانش آموزان آن در نمونـه قرار كرفتــد. جهـت اطمينان از كفايت حجم

3. krejcie \& Morgan

4. Gifted student
اندازه بـيريد و آن رابه صسورت كمّى بيان كنيد، مى تو انيد مدعى باشـيد كـه در بارهُ آن جيزى مى دانيد؛ و گرنه دانش شــما در مورد آن اندكك و نـارســاســت (بـه نقـل از YF). كفتنى اســت تـاكنون براى اندازه كيرى خردمندى دانش آموزان از مقياس هاى خارجى اسـتفاده شـده كه محتواى

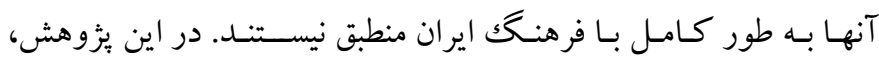
يرســشـــــامـه ســـنش ميز ان خردمنـــى دانش آموزان نوجوان كه تنها يرســشــنامه بومى موجود اســت، مورد ارزيابى قرار كرفته اســت. اين يرسـشــامه داراى ابعاد هشـت كانه و وب گويه اسـت كه براى اولين بار توسط سلمانى، شهريارى و دوايى ' در سال 99 1 ساخته شده است (Y9). با توجه به اهميت دسـترسـى داشــتن به يكك ابزار بومى براى ســنش خردمنـــى در دانش آموزان ايرانى، مطـالعـه حـاضـــر بــا هـدف تعيين شاخص هاى روانسنجى برسشنامه مذكور انجام شده است. بر اين اسـاس و با اين شـرط كه يرسـشـــامه از اعتبار و پيايايى كافى برخوردار بـاشـــد، مىتوان بـا اجراى آن بر نمونسهاى مورد نظر علاوه بر. سـنجش مستقيم ميزان خردمندى دانش آموزان، معنويت و ميز ان بايبندى آنان را به ارزش هاى انسانى، اخلاقى و اجتماعى نيز به صورت غيرمستقيم

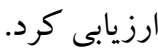

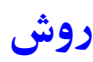
الف) طرح يزوهش و شـر كت كنند كان: مطالعه حاضر به لحاظ هدف جزء بزووهش هـاى توســـهـاى - كاربردى، و به لحاظ شــيوه كرد آورى دادهها از نوع توصسيفى - ييمايشـى اسـت. به منظور بررسـى ويز گىهاى روانسـنجى برسـشنامه سنجش ميزان خردمندى دانش آموزان نوجوان، از روش تحليل اكتشـافى و تأييدى اسـتفاده شـده اسـت. جامعه آمارى اين يزووهش (N= DYNIT)، شــامـل تمامى دانش آموزان تيزهوش و با هوش متوسـط مدارس متوسطه اول شـهر اصفنهان در سال تحصيلى

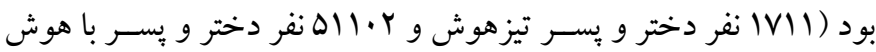

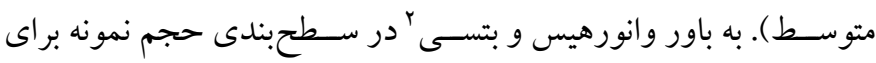

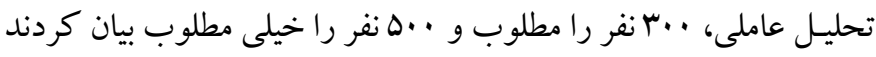

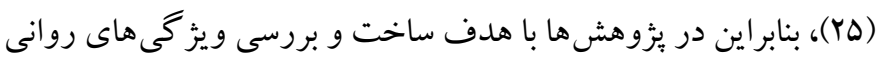
كه در آن تحليل عاملى انجام مى شــود حجم نمونه نبايد كمتر از ... نفر 
حداقل نمره كلى اين برسـشنامه وبو حداكثر •11 خو اهد بود (حد پيايين

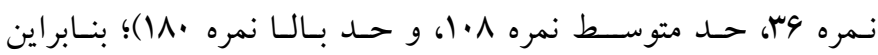
دانش آموزانى كه در اين آزمون نمره ·^| را كسـب كنند، خردمندى بالا و دانش آموزانى كـه نمره 4س را كسـبـ كنند، خردمندى يا يينى خواهند داشــت. با توجه به اين دو معيار، نمره و ميز ان خردمندى ســاير افراد نيز قابل تعيين و تفسـير اســت. در نتيجه مىتوان كفت كه اين برسـشــنامه، مقياسـى دامنهدار اسـت كه نمرات آن روى يكك بيوسـتار از وس تا •11 ادامسه دارد و ميزان خردمنـدى هر شــخص را، موقعيت نمره او روى اين ييوسـتار مشـخص مى كند. بر اسـاس نمره مى توان خردمندى افراد رابه ها

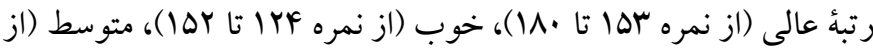
نمره ه9 تا س (1)، ضعيف (از نمره 99 تا FF)، و خيلى ضعيف (از نمره 4M

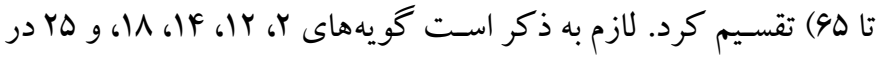
اين برسشنامه به صورت معكوس نمره كذارى مىشوند. ج) روش اجرا: بـا اخـذ مجوزهـاى للازم از ســازمان آموزش و يرورش اسـتان اصـفهان، هماهنكى للزم با مسـؤولان و مديران مدارس متوسطه اول انجام شـد. يس از ورود به مدارس درباره مناسـب بودن شـر ايط و فضاى فيزيكى اطمينان حاصـل شـــ. وقتى امكان تهيه فهرسـت كاملى از اسـامى دانش آموزان وجود نداشـت، در جنين شـرايطى از نمونه كيرى تصـادفى إنى خوشــهاى كه به طور كامل در بخش طرح يزوهش توضــيح داده شــد، اسـتفاده مى شـود. در نهايت از طريق مشورت با مديران مدارس و بررسى نمر ات درسسى دانش آموزان، از تيزهوشسى و ورود سـالم آنان به مدارس اسـتعدادهاى درخشــان اطمينان حاصـل شـــ و در ادامه ضـمن رعايت ملـاحظات اخلاقى و توضــيحات كافى به دانش آموزان، نمونه . .F نفرى

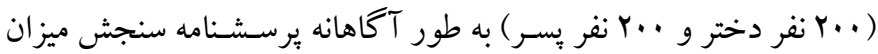
خردمندى را در زمان مناسـب تكميل كردهاند. بعد از اجر ای برسـشـنامه، دادههاى به دست با اسـتفاده از نرمافزارهاى اس بى اس اس و ايموس و با روش تحليل عاملى به دو شيوه اكتشافى و تأييدى انجام شد.

6. Human wisdom

7. Spiritual wisdom

8. Moral wisdom

9. Social wisdom

10 Scientific wisdom
نمونسه آزمون كيزر- مير - الكين ' انجـام شــــ. ملـاكك ورود كروه نمونـه انتخابى، تحصسيل در مقطع اول متوسـطه و برابرى در متغيرهاى سـن، يايه تحصيلى، سـطح فرهنكى، سطح اقتصادى، و محل سكونت بود؛ و ملاكى

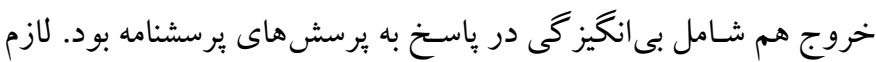

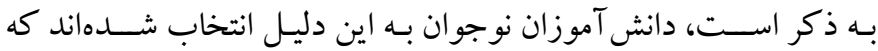
نوجوانى يكى از مراحل مهم تحول انســان به شــمار مى آيد و اين دوره معرف تغيير عميقى اسـت كـه كودكى را از بزر كســال جـدا ســاخته و دكر گونى هاى مختلفى رادر او به وجود مى آورد (YN). ب) ابز ار: ابزار كرد آورى اطلاعات، يرسـشـنامه سنجش ميز ان خردمندى دانش آموزان نو جوان ` تيزهوش و دانش آموزان با هوش متوسط است كه

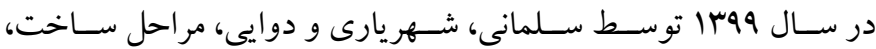
اسـتانداردسـازى و هنجاريابى آن انجام شـده است (Y9). اين برسشنامه به طور كلى ميز ان خردمنـدى دانش آموزان نوجوان و هشــت خرده مقياس (عامل) را مىسنجد. هدف از به كارگيرى اين برسشنامه در اين يزٔوهش، بررسى ابعاد مختلف روانسـنجى آن بوده است. اين برسشنامه داراى 4 كويه از نوع ه گزينهاى بر اسـاس مقياس ليكرت ( كاملا موافقم)" (امو افقم)"

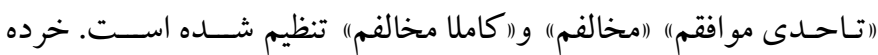
مقياسها عبارت اند از: 1. عامل ارزش هاى عمومى يا خردمندى عمومى

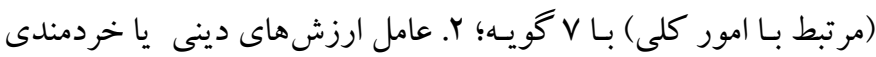

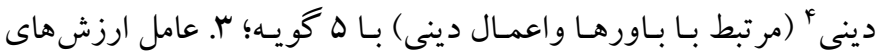
عـاطفى - هيجـانى يـا خردمنـدى عـاطفى -هيجانى ه (مر تبط با هيجانات و احسـاسـات) با ها گوبه؛ F. عامل ارزش هاى انسـانى يا خردمندى انسـانى (مرتبط با عملكر دهاى فردى و شــخصـى مناســب) با ه گويه؛ ه. عامل ارزش هاى معنوى يا خردمندى معنوى V (مر تبط با معنويات) با F كويه؛ 9. عـامـل ارزش هـاى اخلـاقى يـا خردمنـدى اخلـاقى ^^ (مر تبط بـا ارزشهاى

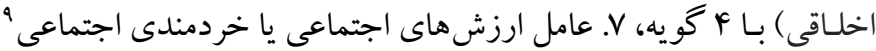
(مر تبط بـا جنبـهـهـاى اجتمـاعى و روابط بين افراد) بـا م كويه؛ و هـ عامل ارزش هـاى علمى يـا خردمنـدى علمى “' (مر تبط بـا جنبـهــاى حقيقت و شناخت) با ب گويه. براساس طيف ليكرت ه گزينهاى و نمرههاى ا تا ه ه ،

1. Kaiser-Meyer-Olkin (KMO)

2. Questionnaire for measuring the wisdom of adolescent students

3. General wisdom

4. Religious wisdom

5. Emotional wisdom 
اندازه مى گيرند يا خير، اعلام كنند. سبس بر اساس فرمول شاخص نسبت

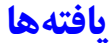

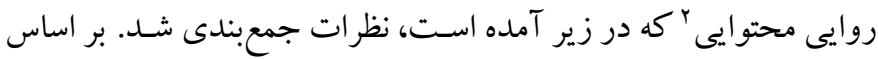

يافتهاى مربوط به تعيين شـاخص هاى روانسـنجى برســــامه سـنجش

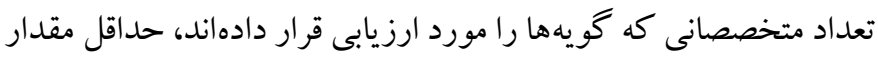
خردمندى در دو بخش روايى و اعتبار ' خزارش مى مورود. روايى محتوايى قابل قبول بايد بيشـتر از صـفر باشـد (YF). دسـت كم عه

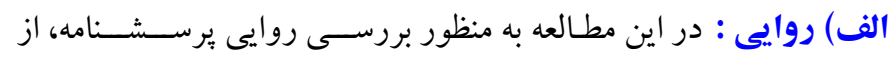

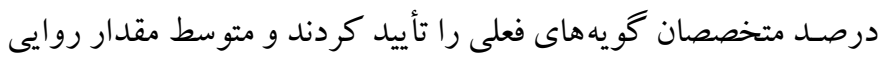

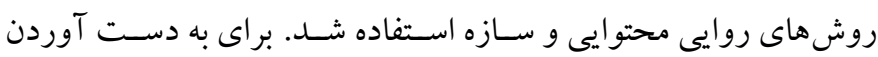

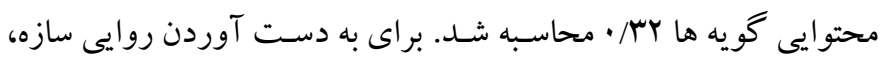

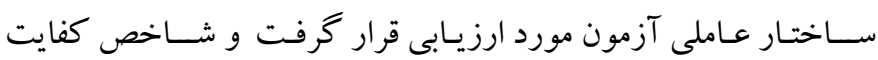

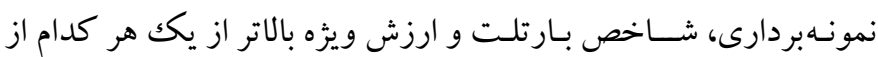

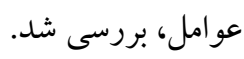

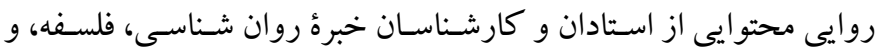

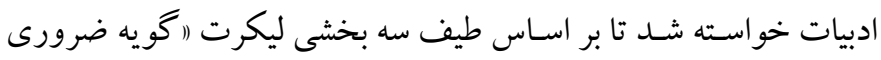

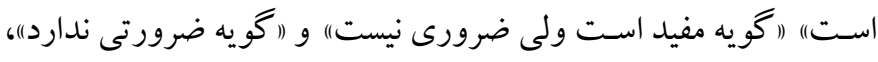

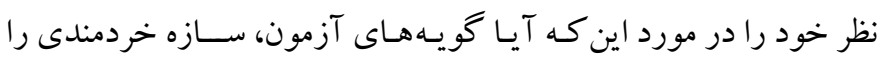

$$
\text { تعداد كل متخصصان }
$$

اســت و معنادارى آزمون بارتلت، حداقل شــــط للازم براى انجام تحليل

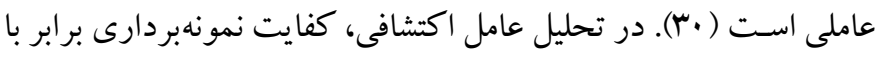

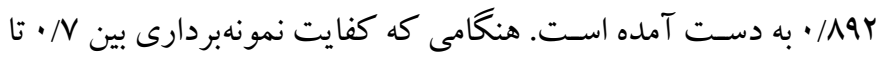

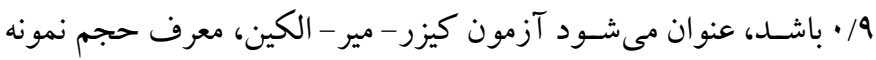

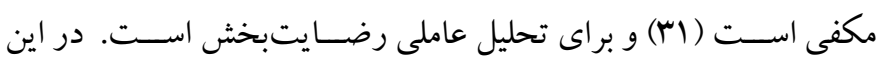

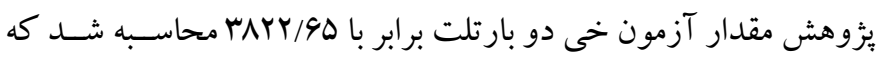

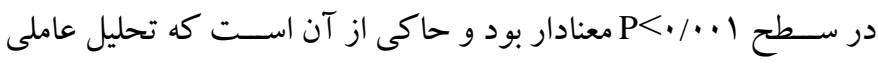
براى شـناسـايى سـاختار مدل عاملى مناسب است. جدول ا شاخص هاى مربوط به تحليل عوامل عامل يابى محور اصلى را نشان مىدهد.
نتـايج تحليل عاملى اكتثــافى: بـا انجام تحليل عاملى روى گويههاى يرسشنامه و با توجه به بالا بودن ضريب همبستكى بين گو يهها و با با اطمينان

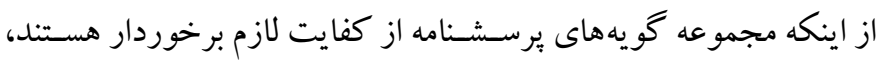

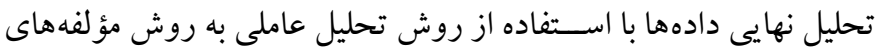

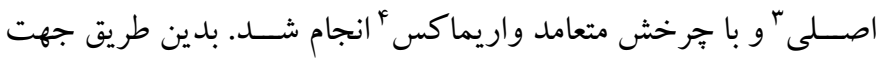

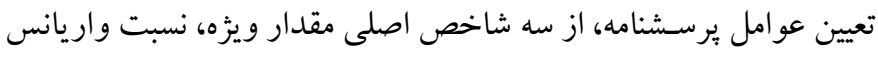

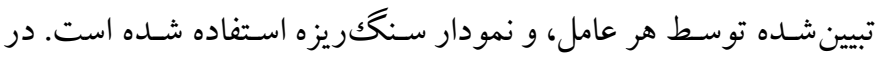

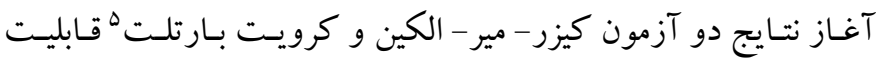
كو يـهـهاى مقيـاس را براى انجـام تحليل عـامـل هـا تأييد كردند. آزمون

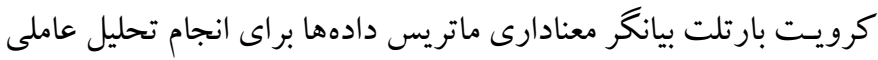

جدول ا: عوامل اكتشافى استخراجشده از يرسشنامه خردمندى

\begin{tabular}{|c|c|c|c|c|c|}
\hline مقدار & وراريانس & اشتراك كويهها* & بار عاملى & كويه (طيف) & 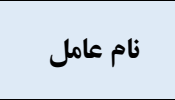 \\
\hline \multirow{3}{*}{$\Delta / 9 / f$} & \multirow{3}{*}{$10 / \Delta 99$} & $\cdot / \mathrm{VDI}$ & $\cdot / \mathrm{WV}$ & هـ. من توانايىام را در جاى مناسب استفاده مى كنم و از خود شجاعت نشان مىدهم. & \multirow{3}{*}{ 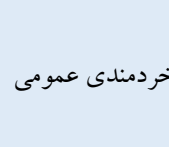 } \\
\hline & & .1990 & $.19 \mathrm{VV}$ & 19. مهم اين است كه در كارها احتياط كنم، حتى اكر ديخران مرا ترسو بدانند. & \\
\hline & & $\cdot / \mathrm{VVr}$ & $\cdot 1919$ & IV به خدا اميدوارم و به مردم خوش گمان هستم. & \\
\hline
\end{tabular}

4. Varimax Oblimin Rotation

5. Bartlett's Test, $\mathrm{K}$
1. Validity and reliability

2. Content Validity Ratio (CVR)

3. Principal Component Method 


\begin{tabular}{|c|c|c|c|c|c|}
\hline & & - var & $\cdot / N r^{4}$ & ·r. براى مناجات و عبادت خدا و حتى براى تفريح، برنامهريزى دارم و آنها را اولويتبندى مى كنم . & \\
\hline & & $\cdot / v \cdot 4$ & $\cdot / \mathrm{Vr}$ & rا ب. به نظرم شناختى كه از خودم دارم باعث شده تا خدا را بهتر بشناسم . & \\
\hline & & $\cdot / \mathrm{AV} \Delta$ & $\cdot / \wedge \Delta 9$ & 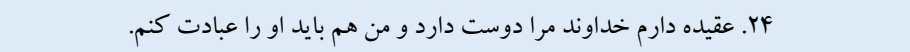 & \\
\hline & &.$/ 91$ & $\cdot / \mathrm{VI}$ & هr. با خدا بودن را حتى اخر تهىدست باشم قبول دارم . & \\
\hline & & $\cdot / \mathrm{A \Delta V}$ & $\cdot /$ / ra & rV فكر مى كنم خيلى از مشكلات از بى توجهى به دستورات خداوند است. & \\
\hline & & $.191 \mathrm{~V}$ & .1911 & •r.r. فقط زمانى احساس خوشبختى مى كنم كه مطيع خداوند باشم. & \\
\hline $\mathrm{F} / \mathrm{AV}$. & Ir/Drq & .191. & .1990 & اس. عقيده دارم بخشى از از مشكلات، امتحان الهى است و بايد از آن يند گرفت. & خردمندى دينى \\
\hline & & $\cdot /$ VAF & $\cdot /$ ArV & 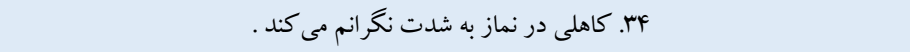 & \\
\hline & & $\cdot / 199$ & $\cdot / \wedge V r$ & 49. تفكر در آفريدههاى خدا به من آرامش مىدهد . & \\
\hline & & $\cdot / A V F$ & $\cdot / 1 \wedge 9$ & 1. هميشه سعى مى كنم آرام حرف بزنم و به اين راحتى آرامشم را از دست نمىدهم. & \\
\hline & & $\cdot / \mathrm{Alr}$ & $\cdot /$ /AS & 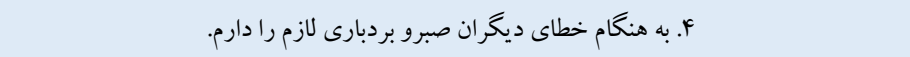 & \\
\hline F/VFD & $\mid r / \Lambda \Lambda$. & $\cdot / v 91$ & $\cdot / \Delta q$ & 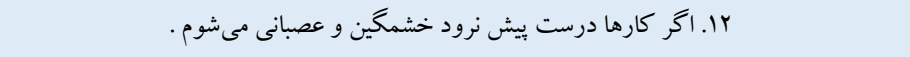 & خردمندى عاطفى \\
\hline & & $\cdot / \mathrm{v} \Delta$ & $\cdot|\wedge|$ & rا. براى رضاى خدا در موقعيتهاى سخت ،خونسردى و شكيبايىام را حفظ مى كنم . & \\
\hline & & $\cdot /$ AFF & $\cdot / \wedge \Delta \mid$ & rrr. هيج وقت از فرا گرفتن علم و دانش خسته نمىشوم. & \\
\hline & & $.19 \mathrm{VV}$ & $\cdot / V Y I$ & بـ مدارا با مردم را للازم مى دانم حتى اخراز نظر اعتقادى با من فرق داشته باشند. & \\
\hline & & $\cdot / 9 V Y$ & $\cdot /$ VYF & ا. ا. اغلب، ديخران را به خاطر بدىهايشان مىبخشم. & \\
\hline F/9AV & $15 / \cdot 19$ & - /AFr & $\cdot / \wedge \Delta \Delta$ & 11. اخر براى خوشبختى ديخران تلاش كنم خودم را خوشبخت مىدانم. & 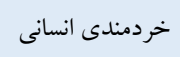 \\
\hline & & .1991 & $\cdot / \vee 99$ & 10. احساس مى كنم اصلا كينهاى نسبت به ديخران ندارم. & \\
\hline & & $\cdot / 999$ & $\cdot / \mathrm{V} 19$ & YN Y بدون استثنا دوست دارم جواب بدى ها را با خوبى بدهم. & \\
\hline & & $\cdot /$ / & $\cdot / \mathrm{V} 99$ & v. گمنامى را خصوصيتى اخلاقى و با ارزش مىدانم و به دنبال شهرت نيستم . & \\
\hline r/Arq & 1.1990 & .1910 & .1949 & 9 ه. خوار شدن در راه خدا را بهتر از سربلندى همراه با دشمن مىدانم. & \\
\hline & & $\cdot / \mathrm{N} \wedge$ & $\cdot / \mathrm{A} \cdot \mathrm{r}$ & rrr. معتقدم هميشه بايد تسليم حق باشم حتى اخر به ضررم باشد. & حردمسىى معوى \\
\hline & & $\cdot / \mathrm{WV}$ & $\cdot / \wedge \mid \wedge$ & بس. امر به نيكى ها و نهى از بدىها را لازم مىدانم، حتى اكر به ضررم باشد . & \\
\hline & & $\cdot /$ / Yr & $\cdot / \mathrm{V} 9 \Lambda$ & ^ عقيده دارم از نشانه هاى خودشناسى، منطقى بودن و تواضع است. & \\
\hline l/9rr & D/MFT & $\cdot / 91$ & . VAr & 19. معتقدم يكى از راههاى رسيدن به اهداف زندگى هم نشينى با علما و دانشمندان است . & \\
\hline & & $\cdot / M \Lambda \Delta$ & $\cdot / \Lambda \Lambda$ & rr. توجه به عاقبت امور را مهم تر از منفعت امور مىدانم . & 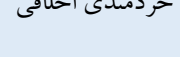 \\
\hline & & $\cdot / A \cdot F$ & $\cdot / A M F$ & צY. به نظرم خودشناسى للزم است و هر كس خود را نشناسد گمر اه مىشود . & \\
\hline & & $.194 r$ & $\cdot / v \cdot 4$ & F أ. معتقدم انسان دانا به دنبال مال و انسان نادان به دنبال كمال است . & \\
\hline I/Far & r/lf. & $\cdot / \wedge \mid \wedge$ & $\cdot \operatorname{l\wedge g}$ & 11. قبل از اين كه به عيوب خود ببردازم، عيوب ديخران را بررسى مى كنم. & 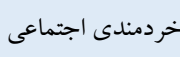 \\
\hline & & $\cdot / \mathrm{AV \Lambda}$ & $\cdot / M V$ & rD. r. معتقدم نگه داشتن راز ديخران خندان اهميتى ندارد. & \\
\hline & & $\cdot / / 9 \cdot 9$ & 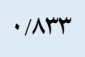 & ك. اغلب بعد از اشتباهاتم نمىتوانم عذرخو اهى كنم . & \\
\hline $1 / 199$ & r/ra9 & $\cdot / N \mu q$ & $\cdot / \wedge \Delta \Delta$ & 9. معتقدم همكلاسىها نبايد از من بترسند. & 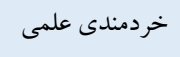 \\
\hline & & .1911 & $.19 \pi /$ & هr. معتقدم زندگى فقط با كسب حلال بايدار خواهد بود. & \\
\hline
\end{tabular}

Communalities:h² *

عامل جهارم (خردمندى انسانى) 19 •/\%1، عامل بنجم (خردمندى معنوى) 1990 • ا، عامل شـشم (خردمندى اخلاقى) سع/M/ه، عامل هفتم (خردمندى

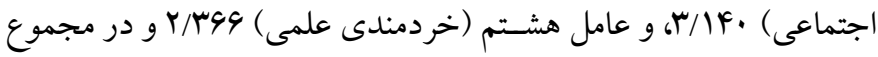
اين هشـت عامل، VI/F9F درصـد از كل واريانس برسـشـنامه را به خود اختصاص دادند.
در جـدول ا، فقط عـاملهاى داراى مقدار ويزه بالاتر از يكك گزارش شـده اسـت و در شكل ا نمودار سنكريزه ارائه شده است. براساس نتايج، بـار عاملى تمامى كويههاى به دســت آمده بيشــتر از ها • و از نظر تبيين واريـانس بـه ترتيـب عـامـل اول (خردمندى عمومى) 10/099، عامل دوم

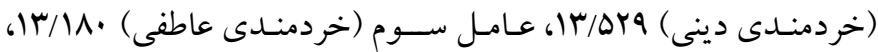




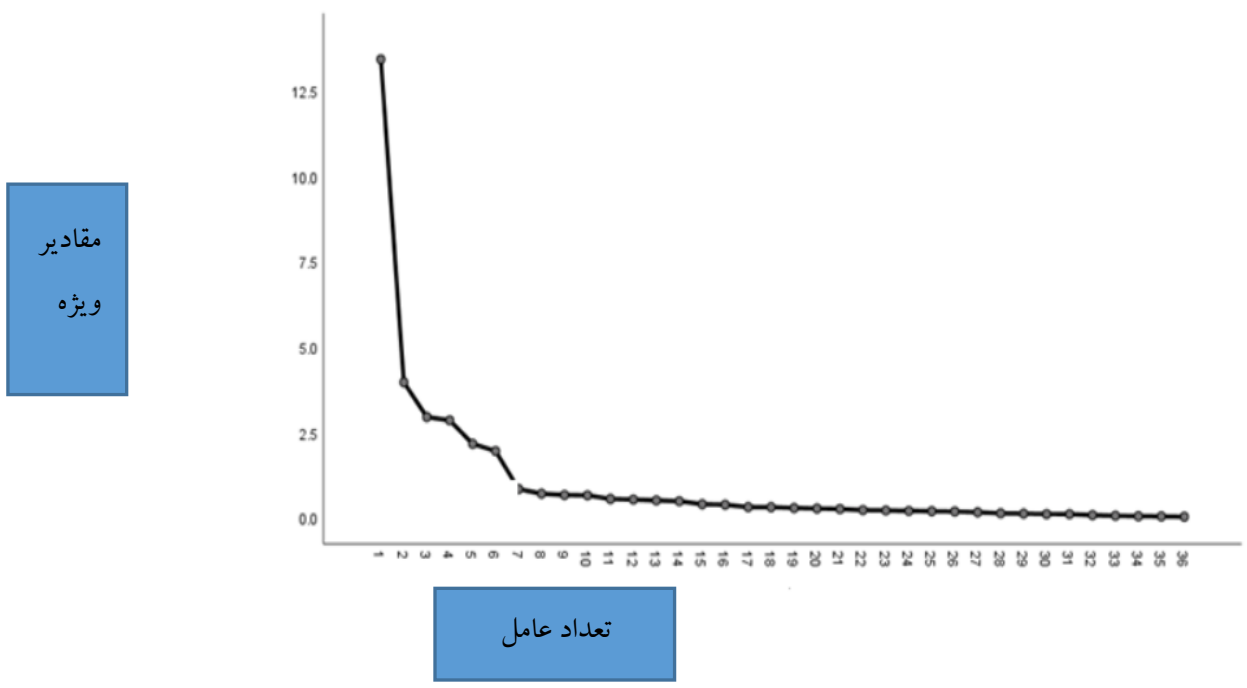

شكل ا. نمودار سنكريزه جهت تعيين تعداد عوامل مناسب قابل استخر اج

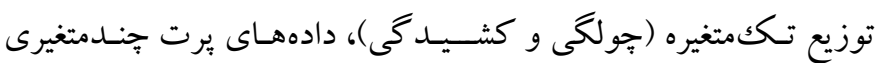
(فاصله ماهالانوبيس) و توزيع نرمال جندمتغيره دادهها (ضريب كشيدكى مرديـا) مورد بررسـى قرار گرفـت. تحليل عاملى تأييدى مرتبه نخســت

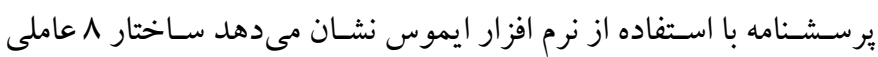
يرسشنامه با دادهها برازش دارد. مقادير برازش براى برسشنامه צب كويهاى

$$
\text { در جدول r گزارش شده است. }
$$

نتـايج تحليل عامل تأييدى مرتبه نخســت: در تحليـل عاملى تأيدى مرتبه نخسـت عامل ها بر اسـاس بر آورد حداكثر درست نمايى' و براساس شــاخص هاى نيكويى برازش مدل معادلات ســاختارى از جمله نســبت مجذور خى به درجه آزادى'، شاخص برازش نرم يارسيمونس ب، شاخص برازش مقايسـهاى ث، شـاخص برازش مقايسـهاى بارسـيمونسه، شـاخص

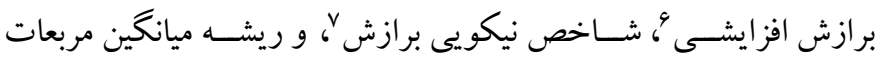

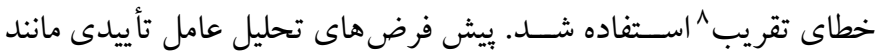

جدول ז: شاخصهاى برازش تحليل عاملى تأييدى يرسشنامه 1 عاملى رفتار خردمندى

\begin{tabular}{|c|c|c|c|c|c|c|c|c|c|}
\hline RMSEA & IFI & GFI & PCFI & PNFI & CFI & درجه آزادى /خى دو & درجه آزادى & خى دو & مدل \\
\hline .1 .49 &.$/ 9.4$ & $\cdot / 9 \cdot Y$ & $.19 \mathrm{MD}$ & $\cdot / 9 \cdot Y$ &.$/ 9.1$ & $1 / \wedge \Delta$ & 099 & $1 \cdot 0 \cdot / \Lambda r r$ & \\
\hline
\end{tabular}

(44 • • • براى مـدلهـايى كه برازندگى خوبى دارند مقدار آن بايد كمتر

از 9. • باشـــ. اين شــاخص براى مدلهاى خوب، هـ • • • و كمتر اسـت.

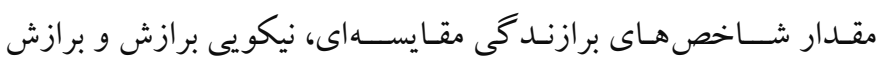
افزايشـى بايد بيش از مقدار ه/ • باشــد تا مدل نهايى يذيرفته شـود. هرجه اين معيار به يكك نزديكك تر باشد، نيكويى برازش مدل با دادههاى مشاهده

5. Parsimonious Comparative Fit Index (PCFI)

6 . Incremental fit index (IFI)

7 . Goodness of Fit Index (GFI)

8. Root Mean Square Error of Approximation (RMSEA)
از آنجا كه هر يكك از شـاخصها تنها جنبه خاصسى از برازش مدل را منعكس مى كنند، بنابراين براى سـنجش برازش مدل، از جندين شـاخص اسـتفاده شـد ( آr). مقدار نسـبت مجذور خحى دو به درجه آزادى در اين تحليل ه/1/ محاسـبه شده است. در اين خصوص مقادير كمتر از س، نشانه برازندكى بيشـتر اسـت. درباره شـاخص ريشـه ميانگين مجذورات تقريب

1. Maximum likelihood estimation

2. Chi-square/degree-of-freedom ratio (CMIN/ DF)

3 . Parsimonious Normed Fit Index (PNFI)

4. Comparative Fit Index (CFI) 


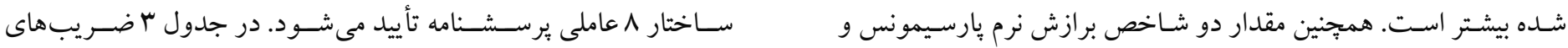

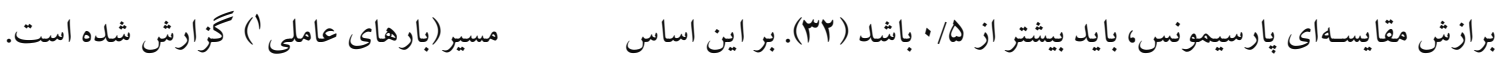

جدول rا: ضرايب مسير ( وزن هاى ركرسيون)

\begin{tabular}{|c|c|c|c|c|c|}
\hline بار عاملى & سوال - عامل & بار عاملى & سوال- عامل & بار عاملى & سوال - عامل \\
\hline$\cdot / f \mid f$ & $r r-\Delta$ & $\cdot / \Delta \Delta r$ & $1-r$ & $\cdot / \Delta r \Delta$ & $\Delta-1$ \\
\hline$\cdot / \mathrm{WI}$ & $\pi-\Delta$ & $\cdot 19 \cdot 4$ & $k-r$ & $\cdot / 0 \cdot V$ & $19-1$ \\
\hline . & $1-9$ & $.194 \mathrm{~V}$ & $\mid r-r$ & . $/ \Delta r$. & $\mid V-1$ \\
\hline$\cdot / \Delta \mathrm{VA}$ & $19-9$ &.$/ F H F$ & r & $\cdot / \Delta V r$ & $r \cdot-1$ \\
\hline$\cdot / 4 \wedge \Delta$ & $r r-9$ & $\cdot / \Delta \mathrm{VA}$ & $r$ rr-r &.$/ 091$ & $r \mid-1$ \\
\hline.$/ \Delta 94$ & YQ-G & $.194 F$ & $r-r$ & . $/ \Delta Y Y$ & $r F-1$ \\
\hline $.19 \Delta \mathrm{V}$ & $r-v$ & $\cdot / 0 \cdot 4$ & $1 \cdot-F$ & $.19 \pi 4$ & $r \Delta-1$ \\
\hline$\cdot / \Delta \wedge \mathrm{V}$ & $M-V$ &.$/ F V \Delta$ & $11-f$ &.$/ 94$. & $r V-r$ \\
\hline . / FrA & $r \Delta-V$ & $\cdot / 4 A I$ & $10-F$ & .1941 & $r \cdot-r$ \\
\hline - TYS & $r-\Lambda$ & $.194 \mathrm{~V}$ & $r \Lambda-F$ & $.191 V$ & rI-r \\
\hline.$/ 499$ & $4-1$ & $.194 V$ & $V-\Delta$ &.$/ 499$ & $r F-r$ \\
\hline$\cdot /$ TVq & $r q-\wedge$ & . $/ F F q$ & $Q-\Delta$ & $\cdot / \Delta \Delta \Delta$ & rq-r \\
\hline
\end{tabular}

روى عامل بنجم بار گذارى شد. ضريب همبستخى عوامل با يكديخر و با

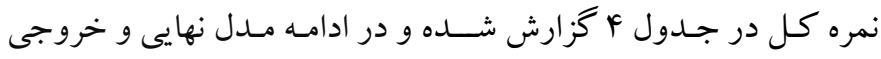
ايموس ارائه شده است.
در مـدل تحليـل عاملى تأييدى، جِنانجه در جدول ملاحظه مى شـــود،

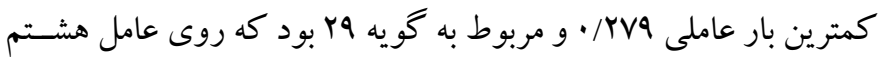

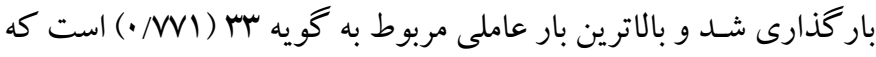

جدول ع: ضريب همبستعى عوامل با يكديكر و با نمره كل

\begin{tabular}{|c|c|c|c|c|c|c|c|c|c|}
\hline كل & 1 & $r$ & 7 & 0 & $\varepsilon$ & $r$ & $r$ & 1 & عامل ها \\
\hline & & & & & & & & 1 & 1 \\
\hline & & & & & & & 1 & 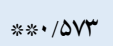 & r \\
\hline & & & & & & 1 & **\%/TVG & ***/DIf & $r$ \\
\hline & & & & & 1 & 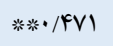 & 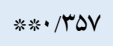 & 䄅光. & f \\
\hline & & & & 1 & *** $* / T V F$ & 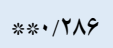 & $* * / \Delta r V$ & ****/DIr & $\Delta$ \\
\hline & & & 1 & 米光. $/ 4.9$ & 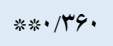 & 䄅前. $/ 49 \Lambda$ & 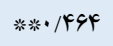 & 䄅光. $\cdot 10.4$ & 9 \\
\hline & & 1 & ***/TMM &.$/ \mathrm{Vr}$ & $\cdot / 109$ &.$/ 19 V$ & سT/ & ***/ra1 & v \\
\hline & 1 & 䄅米・/TV & 䄅䄅・/TYG & 䄅光・/YAF & 米米・ & 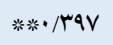 & 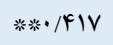 & 䄅光. & $\wedge$ \\
\hline 1 & *** $\%$ ००99 & ***/FAr & ***. 1991 & ***. $199 \mathrm{~V}$ & $* \% / 9 V F$ & **. & ***/VGT & 䄅当·A1I & كل \\
\hline
\end{tabular}

روايى برسشــامه بر اساس ديد كاه آناستازى، ضريب همبستخى بين نمره

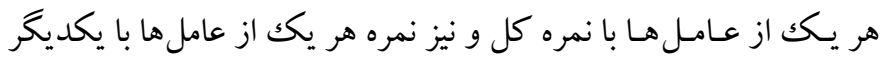

همـان طور كـه ملاحظه مى شــود در جدول \& همبســـــى عامل ها با

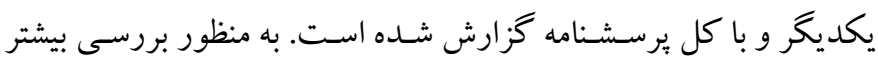




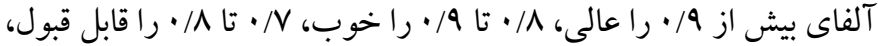

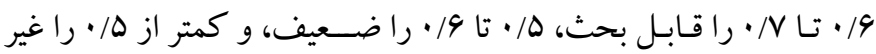
قـابل قبول معرفى كردند (Mr). نوعى ديخر از اعتبار، روش دونيمه كردن ناميده مى شــود كه از طريق تقســم يكك آزمون به دو بخش مســاوى و بررسى ثبات نمرات به دست آمده از دو نيمه به دست مى آيد (Y)). بدين

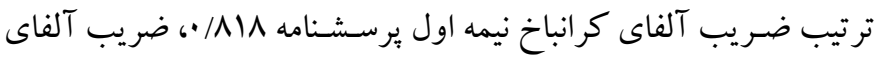

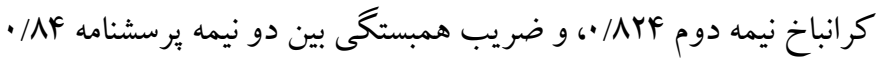
اسـت (جدول ه). با توجه به مقدار ضـريب آلفاى كل (ه9ه/•)، ضـريب آلفاى دو نيمه و ضـريب مناسـب در عو امل هشت كانه، اعتبار برسشنامه احراز شده است. ضر ايب همبستخى بين عامل ها و نمره كل برسشنامه بين

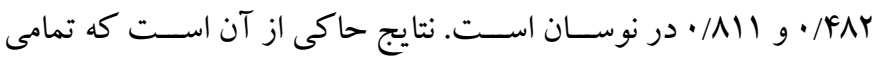

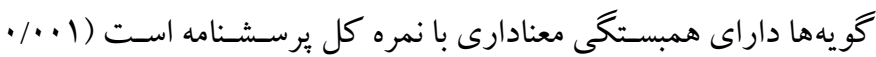

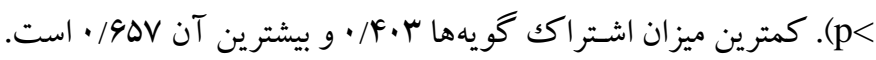
در ادامه خلاصه جداول هنجارى در جدول 4 گزارش شده است.

جدول 0: نتايج روش دونيمه كردن ثيرسنامه حس سوالى براى محاسبه اعتبار

\begin{tabular}{|c|c|c|}
\hline تعداد كويه & مقدار آلفا & نيمهها \\
\hline 11 &.$/ 111$ & نيمه 1 \\
\hline 11 & - /AYF & نيمه Y \\
\hline ra & $\cdot / 19 \Delta$ & كل \\
\hline
\end{tabular}

محاســبه شـــ. همبســــى قابل قبول بين عوامل با نمره كل و همبسـتخى ضعيف بين عو امل هشت گانه برسشنامه با يكديخر، گوياى روايى همخرا

$$
\text { و روايى واكراى عو امل يرسشنامه است (· (1). }
$$

ب) اعتبار: در اين مطالعه اعتبار يرسشنامه به دو روش محاسبه كرديد. 1. روش ضريب آلفاى كرونباخ' r. روش دونيمه كردن r. ضريب آلفا براى

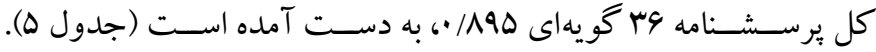
همسـانى درونى كـه آلفاى كرونباخ آن را اندازه گيرى مى كند به معناى اين اسـت كه تا جه حدى تمام اجزا در يكك آزمون، يكك مفهوم يكسـان را بيان كرده و نشـاندهنده ارتباط درونى اين اجزا اسـت (سM). همجنين اعتبار درونى هر يكك از عو امل بدين صسورت محاسـبه شـده اسـت. عامل

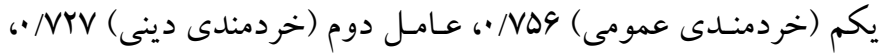
عامل سـوم (خردمندى عاطفى) هD/N1/، عامل جهارم (خردمندى انسـانى)

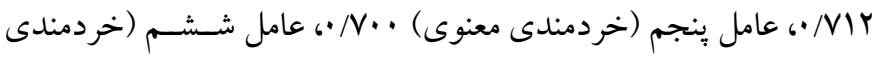

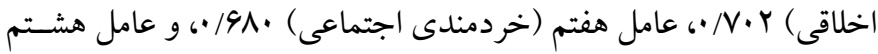
(خردمندى علمى) 9VY •. لازم به ذكر اســت كه حداقل ضــريب اعتبار يرســــامه براى كاربرد در موقعيت بثزوهشى •V/ · و براى ارزيابى بالينى

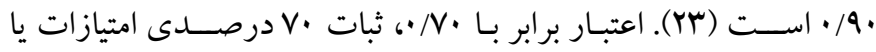
نمرات به دست آمده از يكك ابزار را نشان مىدهد (سM). در نتيجه مىتوان نتيجه گرفت كه اعتبار مقياس مورد اسـتفاده براى هر يكك از عوامل و نيز كل مقياس در حد مطلوب و ايدهآل اســت. برخى متخصــصــان مقدار

جدول 7: خلاصه جداول هنجارى و شاخص هاى آمار توصيفى

\begin{tabular}{|c|c|c|c|c|c|}
\hline $\mathrm{T}$ & $\mathrm{Z}$ & رتبه درصدى & انحراف استاندارد & ميانكين & كروه ها \\
\hline$k q / \cdot r$ & $-.1 \cdot 9$ & \&A & $I V / Y F$ & $\mid \mathrm{FT} / \mathrm{\Delta V}$ & خختران با هوش متوسط \\
\hline$\Delta r / q$. & $\cdot / 49$ & $F \Delta / 9$ & $10 / 91$ & $10 \cdot / r \Delta$ & دختران تيز هوش \\
\hline$F \Delta / v q$ & $-\cdot / F r$ & kq & $\mid V / T$. & $1 \% V / 94$ & يسران با هوش متوسط \\
\hline$\Delta r / 1 \Delta$ & $\cdot / r \mid$ & kq & $19 / Y \Lambda$ & IFN/99 & يسران تيز هوش \\
\hline$\Delta r / \Delta r$ & $\cdot /$ rs & $k q / r$ & $19 / \cdot v$ & $|f q / 9|$ & كروه تيزهوش \\
\hline $\mathrm{FV} / \mathrm{FF}$ & $-\cdot / r \Delta$ & $\Delta r / \Lambda$ & IV/ro & $|f \cdot / \Lambda|$ & خروه با هوش متوسط \\
\hline $0 . / 9 \mathrm{~V}$ & $\cdot / \cdot 9$ & $F \mathrm{~V} / \mathrm{\Delta}$ & $19 / M$ & $|199 / 9|$ & دختران \\
\hline $\mathrm{kq} / .$. & -.1 .9 & 01 & IV/DF & $\mid F T / \Delta r$ & 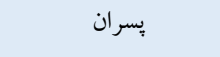 \\
\hline$\Delta . / \cdot$ & $\cdot / \cdot$ & $\Delta$. & $I V / T V$ & $\mid F \Delta / r T$ & يُرسشنامه كل \\
\hline
\end{tabular}


ضريب آلفاى به دست آمده حاصل از اجراى مقياس اشميت، مولدون و يوندرز (1))، معنادارى بيشترى دارد. همجِنين در اجر ایى يرسشنامه وبستر

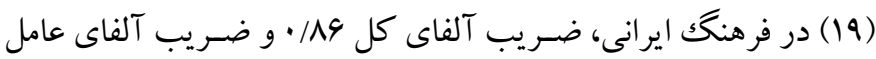
ها به ترتيب

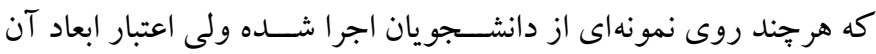

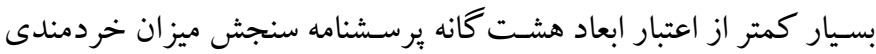
مورد استفاده در اين بثزوهش است.

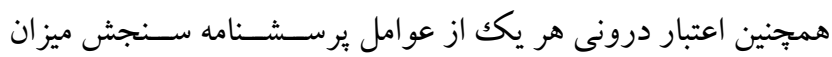

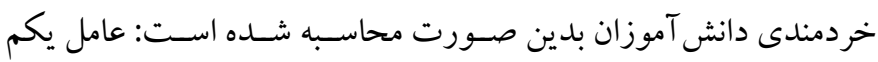

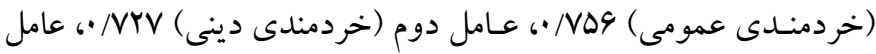

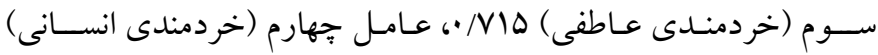

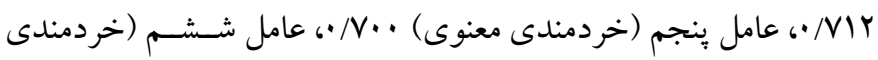

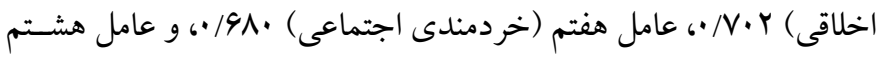

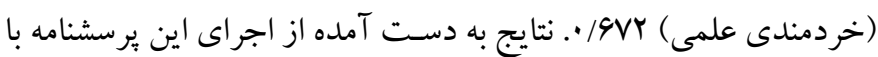

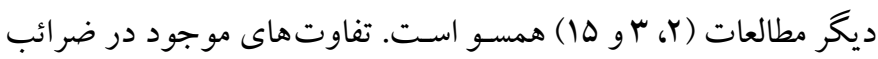

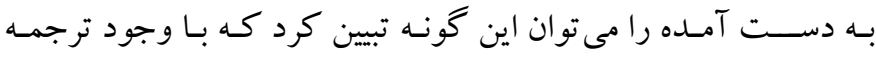

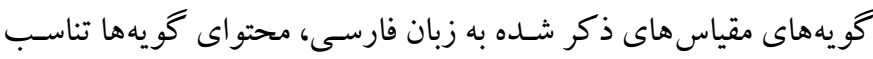
زيادى با فرهنگ اسلامى ايرانى نداشتهاند.

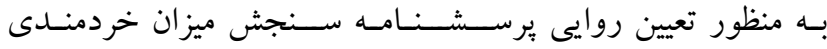
دانش آموزان نوجوان، از روشهـاى روايى محتوايى، روايى ســـازه،

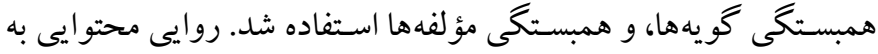
كمك شاخص نسبت روايى محاسبه شد كه مطلوب به دست آمد. نتايج تحليل عاملى با روش مؤلفه هاى اصلى همر اه با جرخ خش واريماكس نشان

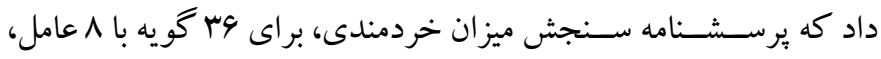
(خ) VI/FqF

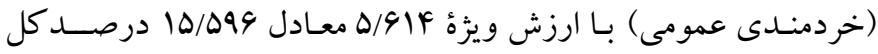
واريـانس را تبيين مى كند كه بيشـترين مشــار كت را در تبيين واريانس يرسـشـنامه بر عهلده داشـته و هشـتمين عامل (خردمندى علمى) با ارزش

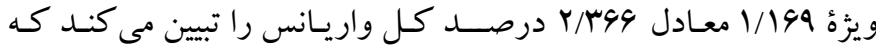
كمترين مشـار كت را در تبيين واريانس برسشـنامه بر عهله داشـته است.

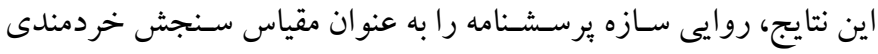

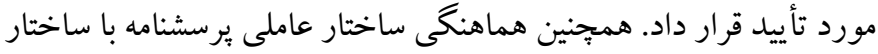

بر اساس نتايج به دست آمده در جدول 9، شاخص ميانگين در گروه

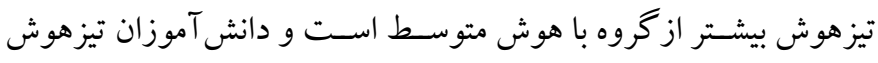
دختر و بسـر، نمره بالاترى در برسـشـنامه شـاخص هاى رفتارى خردمندى

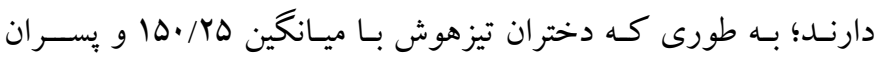

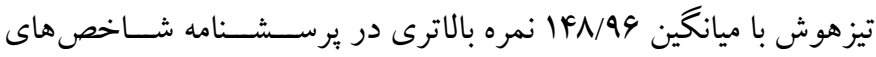
رفتـارى خردمنـدى دارنـــ. بـه عبـارتى خردمندى دانش آموزان تيزهوش بيشتراز دانش آموزان با هوش متوسط است. در مجموع دانش آموزان ابتدا در خردمنـدى عمومى، بعـد از آن در خردمندى دينى نمره بيشـــر، و در

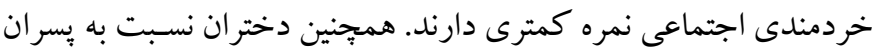
خردمندى بيشترى دارند.

\section{بحث و نتيجه كيرى}

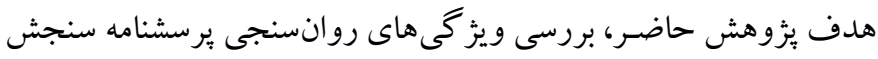

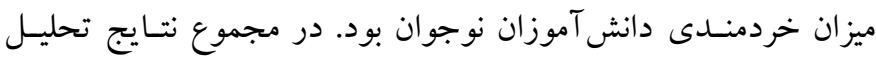
دادهها نشان داد كه يرسشنامه مورد نظر، از كفايت لازم برخوردار است و و برد مى تو اند تصــوير قابل قبول و قابل اعتمادى از اين سـازه ارائه كند. براى تعيين اعتبار يرسشــنامه سنجش ميز ان خردمندى دانش آموزان، با استفاده

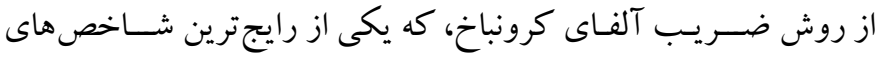

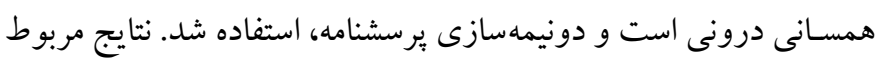

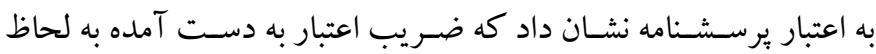
روانسـنجى رضـايتبخش بود. بر اين اسـاس بيشـتر مؤلفهها، دونيمه يرسشــامه و كل مقياس ضـريب بالاتر از V/ • دارند. اين نتايج با مطالعات

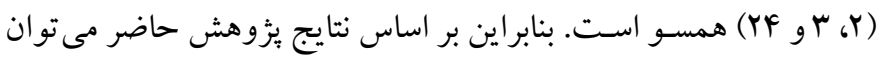

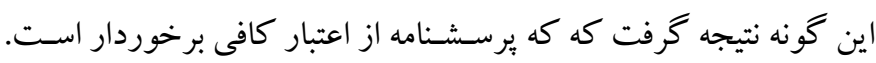

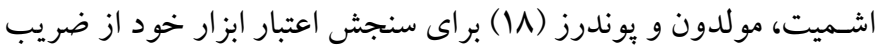

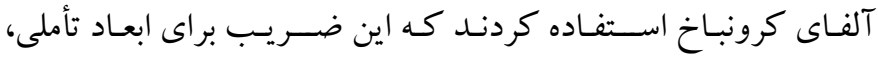

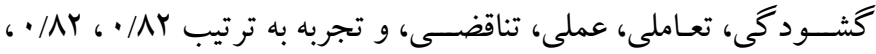

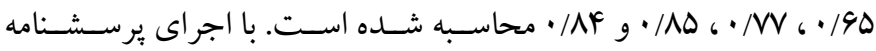

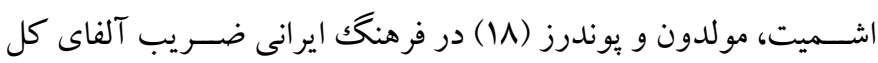

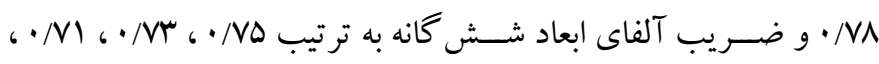

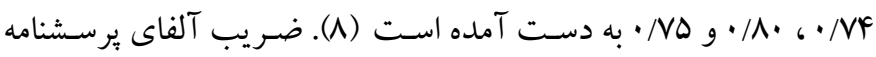

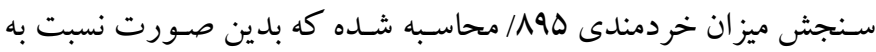


حال هرجّند ميانگين نمره خردمندى در دختران و يُسران تيزهوش نسبت

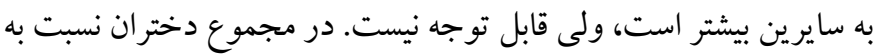

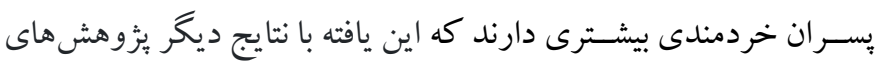

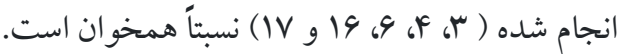
در اينجا للزم است به جند نكته اشاره شود. نخست مطابق با بئوهش

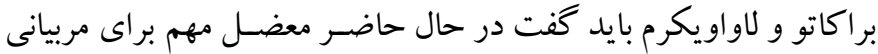

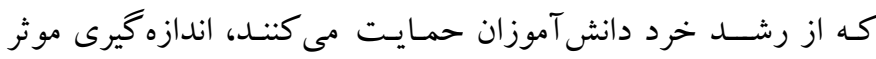

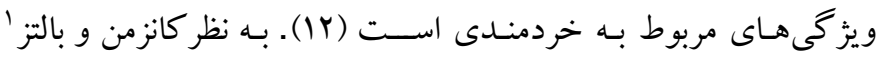

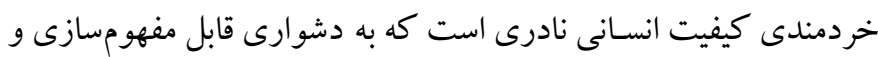
عملياتى شـدن اسـت و ماهيت بيجِيدهُ آن براى مطالعه، يرهزينه و زمانبر

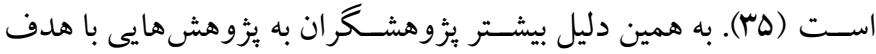

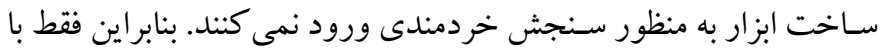

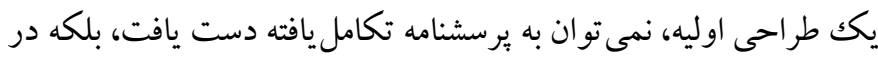

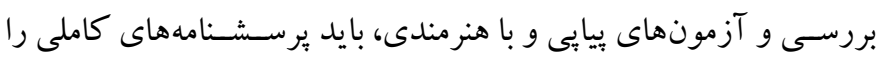

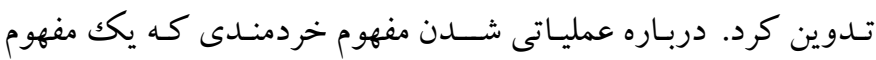

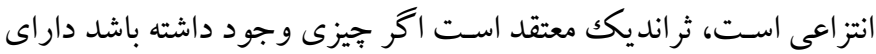

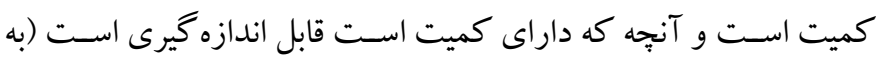
نقـل از YF). در اين خصــوص ييـامبر اســلام مىفرمايد: خداوند در روز

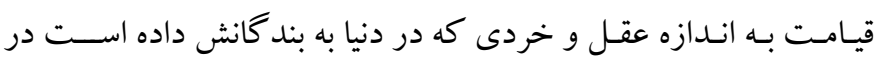

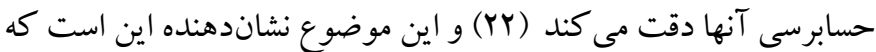

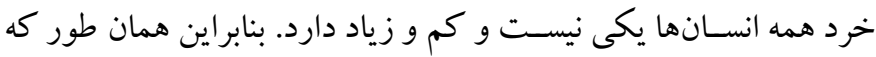
در مقوله هوش درجـات متفـاوتى وجود دارد و برخى تيزهوش و برخى غير تيزهوش هســتند، در خردمنـدى هم عدهاى كمتر خردمند و عدهاى دانا و خردمند هســتند و در نتيجه تعيين ســورح خردمندى مســتلزم به

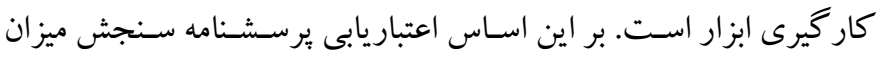

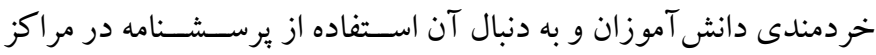

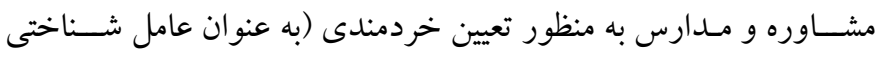

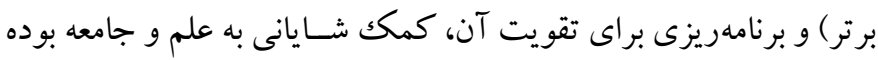

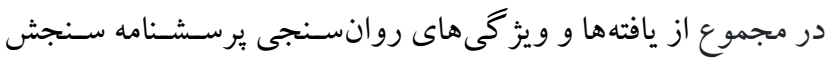
ميزان خردمندى مى توان نتيجه گرفت كه اين برسشنامه ابزار مناسبى براى
نظرى آن مهم ترين شـاخص در تأييد روايى سـازه، براى اين برســــامه

$$
\text { محسوب مىشود. }
$$

نتايج تحليل عاملى تأييدى يرسـشـنامه با اسـتفاده از نرم افزار ايموس نشان داد كه مدل ^ عاملى از شاخص هاى برازش مناسبى برخوردار است. مقـادير نســــت مجـذور خى بـه درجـه آزادى، شـــاخص برازش نرم بارسـيمونس، شــاخص برازش مقايسـهاى، شـاخص برازش مقايسـهاى

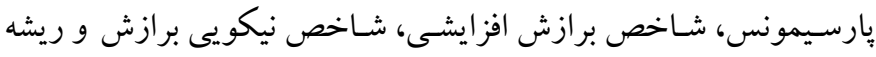

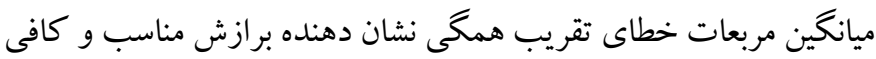

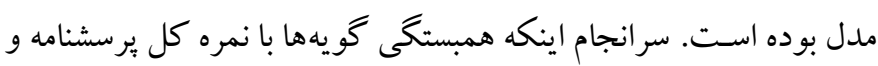

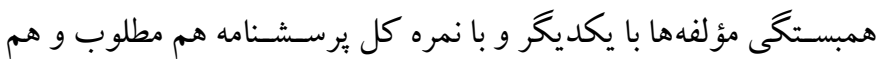
معنادار بو ده و با مطالعات (N) و Y (Y) همسـو اسـت. بنابراين بر اسـاس نتايج

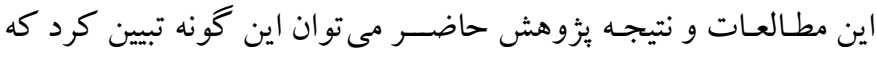
يرسشنامه سنجش ميزان خردمندى از روايى كافى برخوردار است.

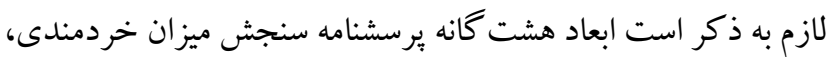
شـامل خردمندى دينى، خردمندى اخلاقى، خردمندى معنوى، خردمندى علمى، خردمنـدى عـاطفى هيجـانى، خردمنـدى انســانى، خردمنـدى اجتمـاعى، و خردمنـدى عمومى بـا برخى از ابعـاد معرفى شـــــه در ديخر

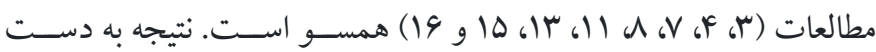
آمـده را مىتوان بر اســاس مطالعـات فوق اين گونه تبيين كرد كه ابعاد

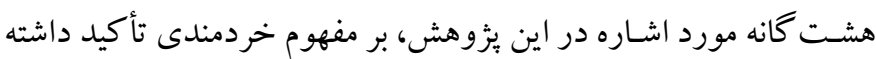
و مطابق با اصول علمى است. در نـمونسه مورد مطـالعـه بيشـترين نمره دانش آموزان، مربوط بـهـ

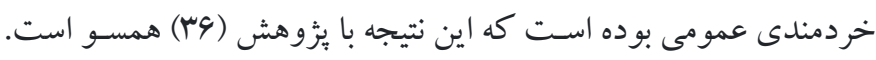

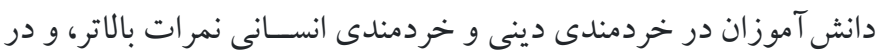

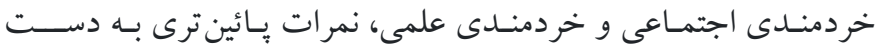

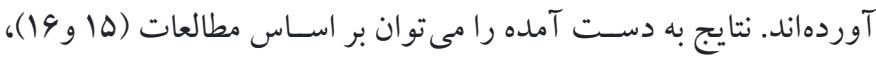

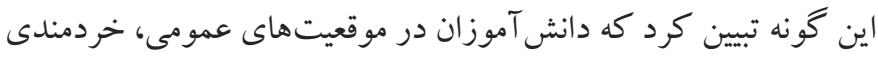
بيشـترى را بروز مى دهند و متناسـبـ با ســين نوجوانى، توجه و اهميت

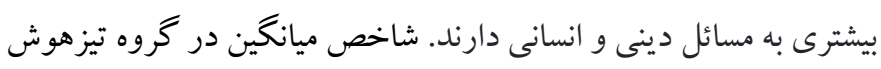

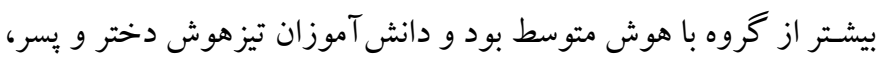
نمره بالاترى در برسشــامه و شاخص هاى رفتارى خردمندى دارند. با اين

1. Kunzmann \& Baltes 
تفكر و فرهنـك مبتنى بر خردمنـدى، عبـادت و ســـــــــت مبتنى بر خردمنـدى، اقتصــاد مبتنى بر خردمنـدى (اقتصــاد مقاومتى)، آموزش و دانش مبتنى بر خردمنسىى، و حتى ورزش و تفريح مبتنى بر خردمنـدى بيردازد؛ موضـوعى كه مى تواند مورد توجه متخصسصـان و يثزوهشــران باشد.

\section{ملاحظات اخلاقى}

ييروى از اصسـول اخلاق يزوهش: مجوز اجراى اين مطالعه بر روى افراد نمونه از

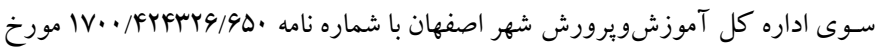
QV/IT/Y. رضـايت كامل افراد نمونه و رعايت اصـل رازدارى و محرمانه ماندن اطلاعات رعايت

شده است.

حامى مالى: اين مطالعه بدون حامى مالى و در قالب رساله دكترا انجام شده است.

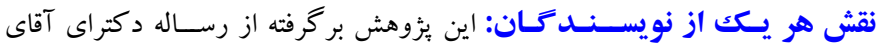
محمدعلى سـلمانى اردانى در رشـته روانشـناسى و آموزش كود كان استثنايى دانشكاه

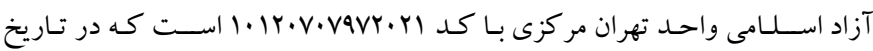

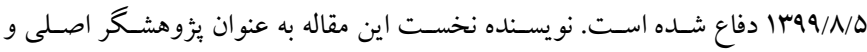
نويسند گان دوم و سوم به عنوان استادان راهنما و مشاور در اين بروزه، نقش داشتند. تضـاد منافع: انجام اين يُزوهش براى نويسند گان هيج گونه تضاد منافع نداشته است و و نتايج آن به صورت كاملاً شفاف و بدون سو گيرى، گز ارش شده است. تشـكر و قدردانى: بدين وسـيله از مســولان اداره آموزشويرورش شـهـر اصـفهان مخصـوصـاً كارشناس يثوهش كه به منظور اجر ایى برسشنامه در مدارس، هماهنكى للازم

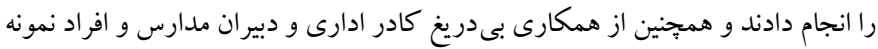
در اجراى اين طرح، تشكر و قدردانى مىشود.
ســنجش ميز ان خردمندى دانش آموزان نوجوان اســت و مى تواند مورد

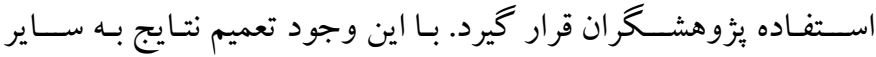

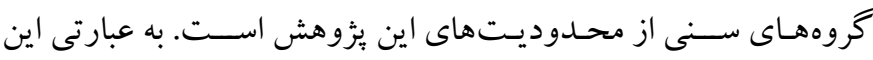
مقيـاس فقط مىتوانسـ ميزان خردمنـدى دانش آموزان نوجوان را مورد سـنجش قرار دهد و نمىتوان از آن در سـطوح كسـتردهتر اسـتفاده كرد. بنـابر اين لـازم اســت جهـت افزايش قـابليـت تعميم نتـايج برســشـــنامه، يثزوهشهـاى مشـــابهى بر روى ســـاير دانش آموزان و در بـافـتهــا و موقعيت هاى ديكر انجام، و يرسـشنامه مجدداً هنجاريابى شود. همجنين به نظر مىرســ، شـواهد بيشـترى لازم اسـت تا معناى محاسـبات و يافته هاى حاصـل از اين بزُوهش روشـن شـود، بنابر اين ادامه مطالعات و يُّوهش ها در اين زمينه، ضــرورى اسـت. با توجه به اينكه در اين برسـشــامه فقط روايى محتو ايى و سازه محاسبه شده است، ييشنهاد مى شود شاخص هاى روايى واكرا و همخر ا از طريق محاسـبه همبســــى اين تسـت با ســاير تسـت هايى كه سـازه خردمندى و سـازههاى غيرمشـابه را مى سـنجند، محاسبه شود.

از ديخر محدوديت هاى اين مطالعه، عدم وجود برسـشـــامه مشــابه داخلى بوده است كه امكان مقايسه شاخص هاى روانسنجى اين برسشنامه را بـا ســاير ابزارهـاى بومى، غيرممكن كرده اســت. بر اين اســاس بـهـ يثزوهشــر ان ييشــنهاد مى شــود به منظور ســنش خردمندى در سـطوح مختلف افر اد جامعه، نسبت به سـاخت و هنجاريابى يرسـشنامه هاى متعدد اقـدام كنتـد. بـايـــ توجه داشــت كه امروزه يكى از خلاءهاى مو جود در جامعه، نبود برنامه هاى مبتنى بر مفهوم خردمندى است. جامعه نياز دارد به 


\section{References}

1. Sternberg, R. Race to Samarra: The critical importance of wisdom in the world today. 2019. https://psycnet.apa.org/doi/10.1017/9781108568272. 002 [Link]

2. Ghorbani R. Khormaei, F. The Examining Causal Model of Wisdom: Explaining Effect of personality and Coping Self-Efficacy. Quarterly Social Psychology Research.2018; 8(31): 33-50. [Persian] [Link]

3. Ghorbani R, Yuosefi F. Structural Relationship between Creativity and Wisdom among a group of Shiraz University Students. Cognitive Psychology Quarterly. 2018; 6 (1): 51-60. [Persian] [Link]

4. Gluck J. New Developments in Psychological Wisdom Research: A Growing Field of Increasing Importance. The Journals of Gerontology: Series B. 2018; 73(8): 1335-1338.https://doi.org/10.1093/geronb/gby102 [Link]

5. Sternberg, R. Words to the Wise about Wisdom?. Human Development. 2004, 47(5): 286289. https://doi.org/10.1093/geronb/gby102 [Link]

6. Ghorbani R. Khormaei F. Explaining Wisdom on the basis of Successful Intelligence and Coping Self Efficacy. Developmental Psychology: Iranian Psychologists. 2018; 13(49): 43-55. [Persian] [Link]

7. Jeste Dilip V. Lee Elen E. The Emerging Empirical Science of Wisdom: Definition, Measurement, Neurobiology, Longevity, and Interventions. The International Journal of Aging and Human Development. Harvard Review of Psychiatry. 2019; 27(3): 127-140. [Link]

8. Akbari A. Hashemi S. Kenari M. The Psychometric Characteristics of Wisdom Scale (WS). Positive Psychology Research. 2016; 2(2): 19-34. [Persian] DOI: 10.22108/PPLS.2016.21334 [Link]

9. Levenson, M., Jennings, P. A., Aldwin, C. M., \& Shiraishi, R. W. Self-transcendence: Conceptualization and measurement. The International Journal of Aging and Human Development. 2005, 60(2): 127-143. https://doi.org/10.2190/XRXM-FYRA-7U0X-GRC0 [Link]

10. Jafari Z. Talepasand S. Rahimian booger A. Psychometric Properties of Wisdom Development Questionnaire in Students. Educational Measurement and Evaluation Studies 2017; 7(17):79-108. [Persian] [Link]

11. Noghabi R. Jahan F. Rashid Kh. Rezaee A. Measure of Wisdom in Iran (Introduce and Validate 3 Scale).
Educational Measurement. 2016; 6(22):187-212. [Persian] [Link]

12. Brocato N. Hix L. Jayawickreme E. Challenges in measuring wisdom-relevant constructs in young adult undergraduate students. Journal of Moral Education. 2020; 49(1): 46-70. https://doi.org/10.1080/ 03057240 .2019. 576124 [Link]

13. Webster J. D. An exploratory analysis of a SelfAssessed Wisdom Scale. Journal of Adult Development.no. 2003; 10(1): 13-22. [Link]

14. Staudinger, U.; Gluck, J. Psychological wisdom research: Commonalities and differences in a growing field. Annual review of psychology. 2011, 62: 215241. https://doi.org/10.2190/XRXM-FYRA-7U0XGRC0 [Link]

15. Willard A. K. Norenzayan A. Spiritual but not religious: Cognition, schizotypy, and conversion in alternative beliefs. Cognition. 2012; 165: 137-146. https://doi.org/10.1016/j.cognition.2017.05.018 [Link]

16. Kordnoghabi R. Delfan Beyranvand A. Arablo Z. Older people's attitudes about wisdom and its components (wisdom Psychology). Aging Psychology. 2015; 1(3):157-167. [Persian] [Link]

17. Asadi S. Amiri Sh. Molavi H. Bagheri Kh. Introducing concept of wisdom in psychology and its Educational Applications. New Educational Approaches. 2013; 6(2): 1-28. [Persian] [Link]

18. Schmit, D.; Muldoon, J; Pounders, K. What is wisdom? The development and validation of a multidimensional measure. Journal of Leadership, Accountability and Ethics. 2012, 9(2): 39-54. [Link]

19. Webster, J. An exploratory analysis of a self-assessed wisdom scale. Journal of Adult Development. 2003, 10(1): 13-22. [Link]

20. DEAN WEBSTER, J. Measuring the character strength of wisdom. The International Journal of Aging and Human Development. 2007, 65(2): 163 183. https://doi.org/10.2190\%2FAG.65.2.d [Link]

21. Ardelt, M; Pridgen, S; Nutter-Pridgen, K. The relation between age and three-dimensional wisdom: Variations by wisdom dimensions and education. The Journals of Gerontology: Series B. 2018, 73(8): 13391349. [Link]

22. Harrani A. tohafolaghul. First Edition. Hasanzade S. Tehran: Ale Ali. 2014; pp: 159. [Link]

23. Rezaei M. Norouzi R. Sepahi M. The Teleology of Intellectual Training in the Individual field from the Perspective of Ayatollah Javadi Amoli. Journal of Research in Islamic Education. 2014; 22(25): 39-57. [Persian] [Link] 
24. Sharifi H. P. Sharifi N. Principles of Psychometrics and Psychoanalysis. Ninth Edition. Tehran: Roshd. 2019; pp: 252-376. [Persian]

25. VanVoorhis, W, Betsy, M. Understanding power and rules of thumb for determining sample sizes. Tutorials in quantitative methods for psychology. 2007; 3(2): 43-50. [Link]

26. Johnson B. Christensen L. Educational Research Quantitative, Qualitative, and Mixed Approach. Persian translator. Khosravi Babadi A. Poushne K. Aghazadeh M. Third Edition. Tehran: Aeig. 2012; pp: 72-116. [Link]

27. Shojaee S. Khamooshi M. A Critical-Analytical Review on Misdiagnosis of Gifted and Talented Students. J Child Ment Health. 2015; 2 (3): 105-115. [Persian] [Link]

28. Badipoor M. Salimi Bajestani H. Kalantarkousheh M. The Mothers' Psychology Empowerment Effectiveness on Mother-Child Conflict decreasing in Health Room of Tehran City. Journal of Clinical Psychology Studies. 2016; 6(23): 95-111. [Persian] DOI: 10.22054/JCPS.2016.4560 [Link]

29. Salmaniardani, M. Shahriariahmadi, M. Davaee, M. Construction, Standardization and Normalization of Wisdom Questionnaire for Adolescent Gifted and Normal Students. [Thesis for Master of Science]. [Esfahan, Iran]: Faculty of Psychology and Educational Sciences, Islamic Azad University Central. 2019; 134. [Persian]
30. Zarea, H. Talebi, S. Seif, M.H. Advanced Inferential Statistics. First Edition. Tehran: Payame Nour. 2010; pp: 206. [Persian]

31. Yousefi N. An Investigation of the Psychometric Properties of the McMaster Clinical Rating Scale (MCRS). Quarterly of Educational Measurement. Quarterly of Educational Measurement. 2012; 2(7). 83-112. [Persian] [Link]

32. Azizi L. Feizabadi Z. Salehi M. Exploratory and Confirmatory factor Analysis of Mazlach Burnout Questionnaire in Tehran University Staff. Quarterly Journal of Psychological Studies. 2008; 4(3). 73-91. [Persian] [Link]

33. Arabzoozani M. Hassani pour S. Bayegi V. Understanding Cronbach's alpha: a necessity for implementation of original research studies. Iran $\mathbf{J}$ Med Educ. 2014; 831-832. [Persian] [Link]

34. Mohammadbeigi A. Mohammadsalehi N. Aligol M. Validity and Reliability of the Instruments and Types of Measurements in Health Applied Researches. Journal of Rafsanjani University of Medical Sciences. 2014; 13(12). 1153-1170. [Persian] [Link]

35. Kunzmann U. Baltes P.B. The Psychology of Wisdom: Theoretical and empirical challenges. A handbook of wisdom, Cambridge University Press. Psychological perspectives. 2005; 135-110. https:// doi.org/10.1017/CBO9780511610486.006 [Link] 